\title{
Plant Responses to Pathogen Attack: Small RNAs in Focus
}

\author{
Waqar Islam 1,+ (iD, Ali Noman 2,3,+ (iD), Muhammad Qasim ${ }^{1}$ (i) and Liande Wang 1,* (iD \\ 1 College of Plant Protection, Fujian Agriculture and Forestry University, Fuzhou 350002, China; \\ waqarislam@m.fafu.edu.cn (W.I.); qasim_gill54@yahoo.com (M.Q.) \\ 2 Department of Botany, Government College University, Faisalabad 38040, Pakistan; alinoman@gcuf.edu.pk \\ 3 College of Crop Sciences, Fujian Agriculture and Forestry University, Fuzhou 350002, China \\ * Correspondence: wang_liande@126.com; Tel.: +86-591-8375-0353 \\ $\dagger$ These authors contributed equally to this work.
}

Received: 26 December 2017; Accepted: 5 February 2018; Published: 8 February 2018

\begin{abstract}
Small RNAs (sRNA) are a significant group of gene expression regulators for multiple biological processes in eukaryotes. In plants, many sRNA silencing pathways produce extensive array of sRNAs with specialized roles. The evidence on record advocates for the functions of sRNAs during plant microbe interactions. Host sRNAs are reckoned as mandatory elements of plant defense. sRNAs involved in plant defense processes via different pathways include both short interfering RNA (siRNA) and microRNA (miRNA) that actively regulate immunity in response to pathogenic attack via tackling pathogen-associated molecular patterns (PAMPs) and other effectors. In response to pathogen attack, plants protect themselves with the help of sRNA-dependent immune systems. That sRNA-mediated plant defense responses play a role during infections is an established fact. However, the regulations of several sRNAs still need extensive research. In this review, we discussed the topical advancements and findings relevant to pathogen attack and plant defense mediated by sRNAs. We attempted to point out diverse sRNAs as key defenders in plant systems. It is hoped that sRNAs would be exploited as a mainstream player to achieve food security by tackling different plant diseases.
\end{abstract}

Keywords: non-coding RNA; plant diseases; genetic control; immunity; defense response

\section{Introduction}

With an increasing global population and shrinking agricultural lands, it is mandatory to increase world food production [1]. Biotic threats to food security include pathogens (bacteria, fungi, nematodes, oomycetes and viruses) as well as insect pests. Cumulatively, these are responsible for an approximately $30 \%$ loss in global crop production at pre- and post-harvest levels [2]. All plant pathogens continuously challenge the host immune system [3], so, to counteract multifarious infection types, plants have evolved an array of defense responses by activating or suppressing a number of genes [4-6]. In succeeding events of pathogen attack, plants recognize a cascade of PAMPs or DAMPs (host danger-associated molecular patterns) [3,7-9]. Cell-surface-based PRRs (pattern-recognition receptors), e.g., FLS2, EF-Tu, LYK5, and CERK1, perceive pathogens, i.e., bacteria- and fungi-triggered PAMPs or DAMPs [10-13]. PAMP as well as DAMP triggers PTI (PAMP-triggered immunity) involving the induction of PR (pathogenesis-related) gene expression, callose deposition, the production of ROS (reactive oxygen species), and SA (salicylic acid) accumulation [14,15]. However, during the course of evolution, many pathogens have evolved effector proteins used for suppressing PTI and culminating in effector-triggered susceptibility (ETS) [16-18]. In response, the plant secondary immune response, commonly called as effector-triggered immunity (ETI), is used as a defense. Moreover, novel resistance (R) proteins are utilized by the plants to recognize the effectors and trigger ETI responses in this 
endless arms race [19]. $R$ proteins usually result in a more vigorous and precise reaction such as a hypersensitive response (HR) [20]. An HR reconciles infection by causing cell death at the infected sites by restricting pathogen growth. Against diversified effectors as a result of defense and counter-defense between hosts and pathogens, plants have evolved new $\mathrm{R}$ proteins to distinguish and tackle new effectors [21-23].

The non-coding RNA molecules that are 20-30 nucleotides (nt) long regulating eukaryotic gene expression through RNA silencing are known as sRNAs [24-26]. In plants, sRNAs are classified into two major categories termed as miRNA and siRNA, respectively. miRNAs are 21-24 nt long and generated from RNAs with imperfectly base-paired hairpin structures [27-34]. siRNAs are obtained from long double-stranded RNAs (dsRNAs) and may need RNA-dependent RNA polymerases (RDRs) [35,36]. Several sub-classes of siRNA have been reported in plants, inclusive of ta-siRNAs (trans-acting siRNAs), hc-siRNAs (heterochromatic siRNAs), nat-siRNAs (natural antisense transcript-derived siRNAs), and lsiRNAs (long siRNAs) [37]. Post-transcriptional gene silencing (PTGS) or transcriptional gene silencing (TGS) is mainly responsible for sRNA-mediated gene regulation in hosts or pathogens [38]. miRNAs and siRNAs can induce PTGS by mRNA (messenger RNA) cleavage/degradation or translational repression through RISC (RNA-induced silencing complex) [5,39]. Contrarily, TGS, ending at either DNA methylation, histone modification, or chromatin modification, is generally mediated by siRNAs and some specific miRNAs as well [40,41]. The biogenesis of different sRNAs is complex and species-specific, and in spite of some common steps, many steps are exclusive for certain sRNAs. Regarding the biogenesis of various sRNAs, much data are available [39,42-47]. Therefore, due to the immense implication of sRNAs in plant immunity, we have summed up the targeted functions of sRNAs as front line players in mediating plant growth under pathogenic pressure. We mention recent advancements in sRNA research, particularly explaining their role as a dynamic network in mediating plant immunity against pathogens.

\section{Plant sRNAs against Pathogen Attack}

Different plant diseases due to phyto-pathogens cause substantial damages to crop production and ultimately result in heavy economic losses [6]. These pathogens include bacteria, fungi, mycoplasma, nematodes, viruses, viroids, and parasites. Various groups of plant sRNAs play vital roles in plant defense against pathogens. sRNAs involved in plant defense processes via different pathways include both siRNA and miRNA that actively regulate immunity in response to pathogenic attack via tackling PAMPs and other effectors [48-52] (Figure 1). Against pathogen attack, up-/down-regulation of sRNAs lead to the suppression of target site expression [37]. However, regulations of several sRNAs still need extensive research. Multiple proteins take part in sRNA pathways for initiating successful defense response to the pathogens through sRNAs biogenesis and functions. These proteins include (a) endoribonuclease DICER or DICER-like (DCL) involved in the production of sRNAs, (b) argonautes (AGOs) performing sRNA-directed gene suppression, and (c) RNA-dependent RNA polymerase (RDRs) taking part in the genesis of dsRNA precursors [53]. The genome of Arabidopsis thaliana encodes four proteins in which DCL1 is regarded as the vital one in connection with miRNA genesis. Several miRNAs are related to ETI and PTI against fungal and bacterial attacks. A. thaliana mutants, i.e., $d c l 1-9$ [54] and $d c l 1-7$ [55] were found to be susceptible to pathogen infections. This illustrates the regulation of immune responses through miRNAs. Other proteins like DCL4 are liable to siRNA generation and is important against pathogen attack, e.g., bacteria, fungi, and viruses [56,57]. AGOs also regulate the immune process. For example, bacterial infection in $A$. thaliana results in the generation of AGO2, so its mutant ago2-1 in tomato embedding miRNA393 is considerably susceptible towards several prominent strains of Pseudomonas syringae [58]. It is interesting to note that miRNA393 works through AGO1 for the suppression of auxin receptors for the activation of anti-bacterial immunity [59]. AGO1 mutants (ago1-25 and ago1-27) actively acquired immunity against bacteria. Of note, these mutants were also found to be resistant to fungal infection $[60,61]$. The $A$. thaliana genome possesses six RDRs. RDR6 produces secondary siRNA, i.e., ta-siRNA. The $r d r 6$ mutant is 
highly susceptible to fungus [60] but is resistant to Pseudomonas strains [62]. Furthermore, mutations due to the interface of RDR6 and antiviral proteins (SGS3) also enhance the susceptibility towards Verticilium infections [60]. Thus, it can be inferred that sRNA pathways are more important in the functioning of anti-fungal defenses in plants.

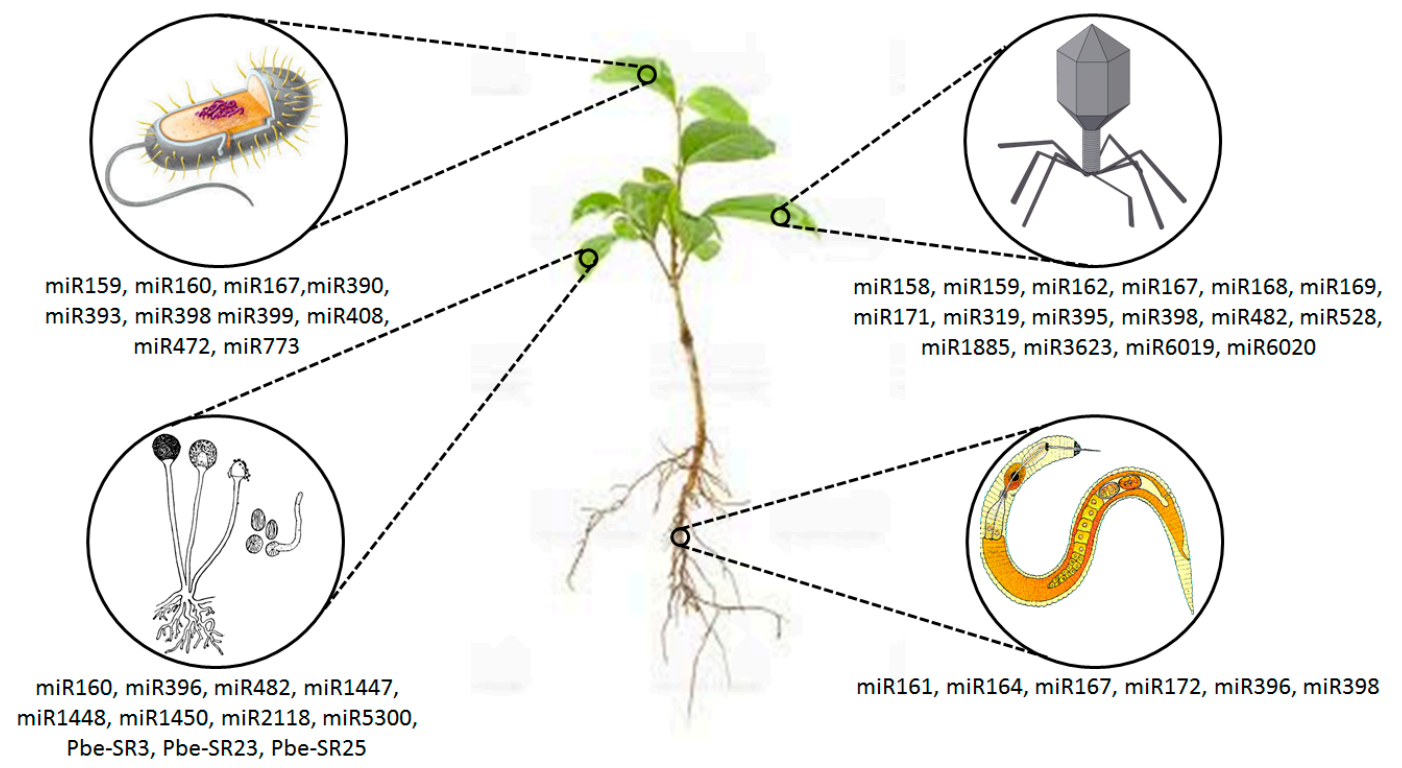

Figure 1. The role of small RNAs (sRNAs) against infection of various pathogens (general illustration).

DNA methylation and histone modification are directed through hc-siRNA and induces transposons silencing, palindromic repeats, and genes at the transcriptional stage. This RNA-directed DNA methylation (RdDM) pathway is also involved in immunity regulation [63-65]. Mutants materialized through RdDM show phenotypic disease modifications against bacterial and fungal infections. This is supported by the fact that a triple mutant of the non-cytosine (CG loci) methyltransferases (drm1-2/drm2-2/cmt3-11) with POL-IV subunit presented high resistance to $P$. syringae virulence [66]. Likewise, low expressions of different RdDM pathway proteins as a result of $P$. syringae virulence have been observed. PAMP-activated flg22 supports the view that antibacterial defense gene expression is transcriptionally regulated by RdDM [67]. Contrarily, ROS1 encoding for 5-methylcestocine DNA glycosylase that initiates active DNA demethylation is repressed upon flg22 treatment, and its mutants are greatly susceptible to $P$. syringae infections [67]. This favors the view that defense tactics against pathogen attacks cause active DNA demethylation which is a part of the regulatory circuit for gene activation in response to pathogen attacks. Arabidopsis RdDM mutants (nrpe1 E ago4) and rdd, i.e., triple DNA demethylase mutant (ros1/dml2; DEMETER-LIKE 2/dml3; DEMETER-LIKE 3) revealed susceptibility against Fusarium oxysporum attack [65]. Obviously, DNA demethylation or RdDM re-arranges the transcriptional status of various immunity genes. Enhanced susceptibility against necrotrophic fungal pathogens (Botrytis cinerea and Plectospherella cucumerina) was observed in the ago4,drd1, rdr2,drm1 drm2, and nrpd2 mutants, which is contrary to the increased resistance against bacterial pathogens [68]. For this reason, sRNA and their associated pathways are critical factors in regulating the host immunity towards pathogen attack.

\section{Plant Small RNAs against Viruses and Viroid Infections}

Plants are affected by viruses and viroids due to their replicating genomes in the host cells [69-71]. PTGS was primarily recognized in transgenes with Potato virus X (PVX) infection. During investigation, sRNAs complementary to the sense transcript of the transgene and the positive strand of PVX were revealed, which indicates sRNA participation in viral defense and PTGS transgene silencing [72,73]. 
Studies have demonstrated virus and viroid replication along with RNA genomes and transcripts folding to generate dsRNAs that might play a role in RNA silencing machinery [74] (Figure 2).

Viruses possess ssRNA, dsRNA, ssDNA, or dsDNA genomes $[26,75,76]$. During the replication of an ssRNA viral genome, a complementary strand of RNA is synthesized, which forms a long dsRNA with the original viral genome. The dsRNA replication intermediate ssRNA types and the dsRNA genomes of dsRNA viruses can be targeted by a host RNA silencing apparatus [53,77]. Approximately equivalent quantities of positive- and negative-stranded virus-derived small interfering RNAs (vsiRNAs) without positional bias were derived from different families such as Cucumber yellows closterovirus (CuYV), Turnip mosaic potyvirus (TuMV), Cucumber mosaic virus (CMV), Watermelon mosaic virus (WMV), PVX, and Tomato yellow leaf curl virus (TYLCV) [78-82]. Interestingly, positive and negative strands of Rice stripe virus (RSV) generated an equal amount of vsiRNAs [83]. On the other hand, over $80 \%$ of vsiRNAs produced from the positive strand have been obtained from Cymbidium ringspot virus (CymRSV) [84,85]. Similar phenomena are evident in plants infected with other ssRNA viruses, i.e., TCV, TMV, TRV, and PMMoV (Pepper mild mottle virus). In these examples, some positive strand vsiRNAs accounted up to $97 \%$ of total vsiRNAs $[79,81,86]$. There are no dsRNA intermediate replicative forms for ssDNA and dsDNA viruses. Some of the vsiRNAs from DNA viruses show that vsiRNAs might be processed from the structured part of the viral RNA transcripts. Sixty-two percent of the vsiRNAs resemble the CaMV (Cauliflower mosaic virus) transcript polarity, a common source of constitutive $35 \mathrm{~S}$ promoter. Nearly $82 \%$ vsiRNAs are synthesized from the leader region, with no strand bias [37,87]. A geminivirus, namely Tomato yellow leaf curl China virus (TYLCCNV), possess an ssDNA genome. Although the vsiRNAs generated from TYLCCNV present a site bias, they map approximately equal to the negative and positive genomes $[83,88]$. Consequently, dsRNA replicative forms and the viral genomes secondary structure can be processed by host RNA silencing apparatus. However, the finalized opinion on viral pathogenicity with respect to these findings is still unknown.

Viroids, the smallest pathogens replicating inside the nucleus or chloroplast, are comprised of naked, single-stranded, and circular RNAs that are 250-400-nt in size [74]. Two decades ago, full methylation of the Potato spindle tuber viroid (PSTVd) cDNA sequence was observed in PSTVd-infected tissues $[89,90]$. The viroid-induced RNA silencing and RdDM are responsible for this methylation. Later, it was confirmed that viroids are the activator and target of RNA silencing in infected tomato and tobacco plants [91,92]. Viroid-related siRNAs (vdsiRNAs) of PSTVd are produced from polarities in the right and left domains. With the help of deep sequencing profiling of PSTVd vdsiRNAs, it was revealed that PSTVd vdsiRNAs chiefly map to the positive strand of the right and left terminal regions. This observation indicates that these sRNAs are produced from the secondary structure of positively stranded RNAs. A number of vdsiRNAs are also produced by the negative strand of the central part presenting their probable processing from the secondary structure of the negative-strand viroid genomic RNA [93]. Citrus exocortis viroid (CEVd) after replication mainly generates $5^{\prime}$-phosphorylated and $3^{\prime}$-methylated vdsiRNAs with positive polarity. Most CEVd vdsiRNAs are localized within the right-end domain. This proposes that structured RNA is the vital substrate of DCL enzymes [94,95]. Some viroids such as Chrysanthemum chlorotic mottle viroid (CChMVd), Peach latent mosaic viroid (PLMVd), and Avocado sunblotch viroid (ASBVd) replicate in the chloroplast. Both PLMVd and CChMVd produce vdsiRNAs from negative and positive polarities [96,97]. ASBVd also produces vdsiRNAs in leaves exhibiting infection symptoms [98]. Therefore, both viroid families, i.e., Avsunviroidae and Pospiviroidae, possess a capacity to generate vdsiRNAs in different plants $[99,100]$. Generation of vdsiRNAs from both the positive and the negative strands of the viroid genome highlight the predominant processing of vdsiRNAs from the viroid genomic RNAs secondary structure. Nevertheless, it is pertinent to indicate that the biasness in discoveries of vdsiRNAs depends upon the methods applied for sRNA cloning. 


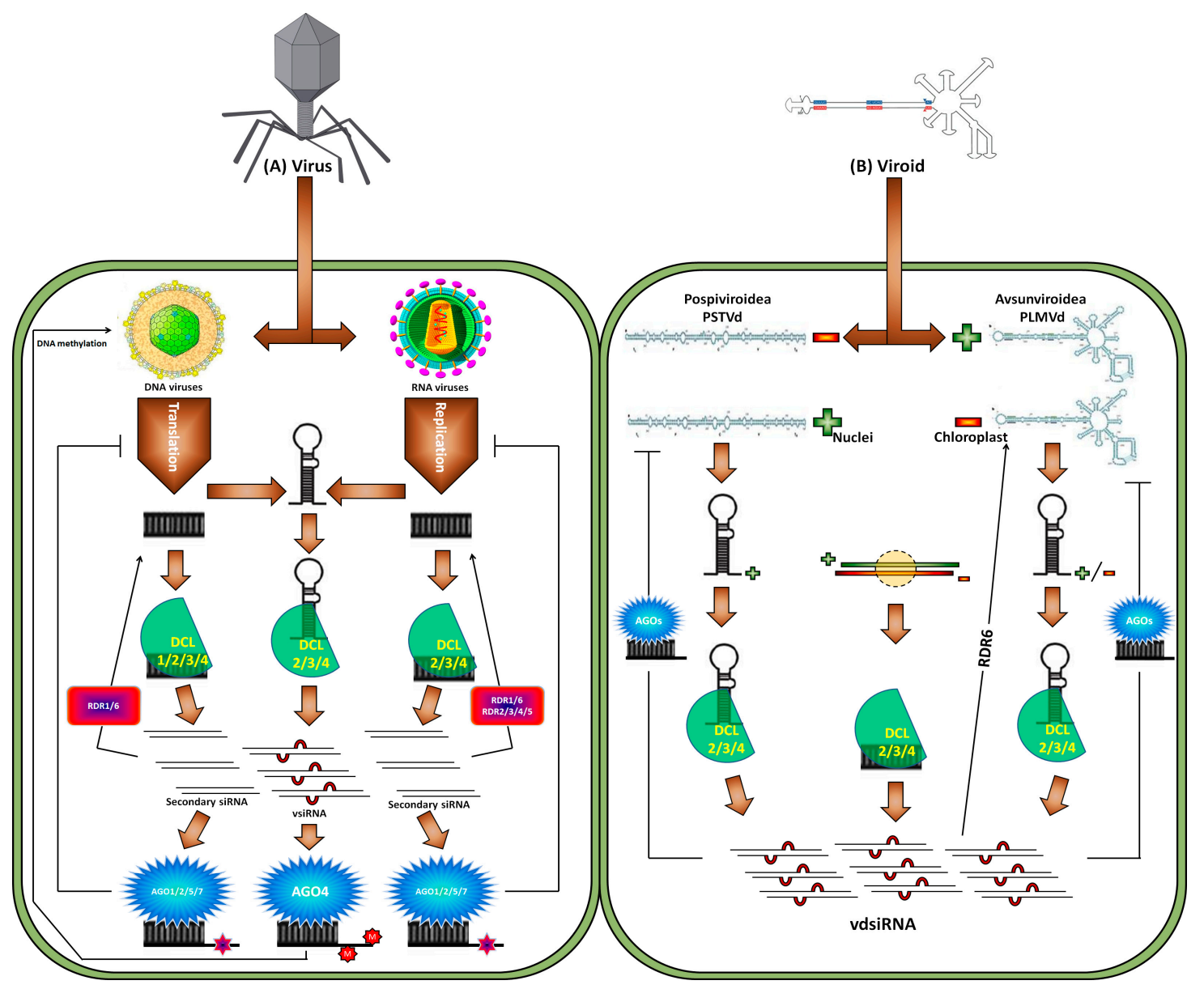

Figure 2. (A) The role of sRNAs against viruses and viroid infections in plants. (A) Numerous virus-derived small interfering RNAs (vsiRNAs) are generated in plants that directly target the viral genomes to initiate defense against virus infections. The generation of vsiRNA regarding DNA viruses and RNA viruses are explained here. Regarding DNA viruses, the vsiRNAs are processed via the structural region of the transcripts along with the overlapping regions of the bi-direction transcription. On the contrary, upon the infection of RNA viruses, the structure region of viruses can be processed through DCL proteins. However, in both cases, secondary vsiRNAs are coordinated by RDR1 and RDR6. After production, these vsiRNAs are loaded into different argonautes (AGOs), which further play a role in virus genome silencing. vsiRNAs silence the genomic RNA upon RNA virus infection. However, upon the infection of DNA viruses, DNA methylation is initiated through these vsiRNAs. (B) Potato spindle tuber viroids (PSTVds) are found in nucleolus and their viroid-related siRNAs (vdsiRNAs) show predominant mapping to the positive strand of the left and right terminal regions. It is thought that the generation of these vdsiRNAs is linked to the hairpin loopy structure of positive strand of PSTV transcripts. The secondary structure of PSTVd transcripts are targeted by DCL protein and sliced into vdsiRNA. vdsiRNA can also be generated by the accidental association of positive and negative strand replication, further regulated by DCL proteins. Oppositely, PLMVds replicate inside the chloroplast and have the ability to generate vdsiRNAs from both positive and negative strands. The stem-loopy or hairpin-like structure of PLMVd is processed through various DCL proteins to produce vdsiRNAs. It is also illustrated that amplification of vdsiRNAs through RDRs is also possible, and the generation, the vdsiRNA can be loaded into plant AGO proteins leading towards the targeting of viroid RNAs.

The plant DCL proteins process inducers of dsRNA for production of sRNAs. The model plant Arabidopsis possesses four DCL proteins that are used to generate diverse sRNAs [43]. DCL1 cleaves hairpin primary micro RNAs (pri-miRNAs) into a smaller stem-loop structure called precursor 
microRNAs (pre-miRNAs), which are subsequently processed again by DCL1 to produce mature miRNA duplexes consisting of the active miRNA strand and its complementary strand miRNA [101]. DCL2-4 produces siRNAs with specific sizes (22, 24, and $21 \mathrm{nt})$ from long perfect dsRNAs [102]. For instance, DCL2, -3 , and -4 , respectively, produce nat-siRNAs, hc-siRNAs, and ta-siRNAs, but DCL4, -2 , and -3 , redundantly produce viral siRNAs to defend against virus infection [103-106]. Predominant dsRNA inducers for RNA viruses and viroids include the perfectly paired dsRNA intermediate replication form and the hairpin structure of the single genomic RNA. Indeed, DCL2, -3 , and -4 are accountable for processing ssRNA viruses, e.g., CMV, TuMV, and TCV, into 21, 22, and $24 \mathrm{nt}$ vsiRNAs, respectively [107-111]. The new leaves in PSTVd-infected plants simply accrue small (21-22 nt) vdsiRNAs, in contrast to the older leaves having shorter as well as longer (24 nt) vdsiRNAs $[112,113]$. Analogous vdsiRNA buildup patterns have been observed in plants attacked by Hop stunt viroid (HSVd) and Hop latent viroid (HLVd). However, very few reports are available regarding vdsiRNAs biogenesis. The accumulation of 21, 22, and $24 \mathrm{nt}$ vsiRNAs has also been recorded in plants infected with Beet curly top virus (BCTV), Cabbage Leaf Curl Virus (CalCuV), and Pepper golden mosaic virus (PepGMV). Notably, all of these are ssDNA viruses except CaMV, which is a dsDNA virus $[87,114,115]$. From DNA viruses, the predominant production of $24 \mathrm{nt}$ vsiRNAs is on record. As stated earlier, DCL proteins like DCL2, DCL3, and DCL4 are crucial for the accumulation of different $\mathrm{CalCuV}$ vsiRNAs. Plants infected with BCTV, DCL3, and DCL4 were found to be responsible for amassing 21 and $24 \mathrm{nt}$ vsiRNAs [115]. In spite of the mandatory role of the hairpin structure of viral or viroid genomes for the production of vsiRNA and vdsiRNAs, DCL1-dominant hairpin processing is not involved in vsiRNA and vdsiRNAs accumulation or anti-RNA-viral resistance. However, DCL1, not DCL4, is needed for the increase in $21 \mathrm{nt}$ vsiRNAs from CaMV [87].

Following the early processing of dsRNA inducers, both the antiviral and anti-viroid signals are amplified by host RDRs. In A. thaliana, out of six RDRs, the functions of RDR1, RDR2, and RDR6 are well studied. SA and TMV infection induce RDR1 in tobacco and Arabidopsis. A mutation in RDR1 allows well-organized development of ssRNA viruses [116,117]. Moreover, the AtRDR6 mutant appeared highly susceptible to the attack of ssRNA and ssDNA viruses [118]. Decreased expression of rice RDR6 was observed after infection with RSV and RDV (a negative ssRNA virus and a dsRNA virus, respectively). Additionally, OsRDR6 down-regulation by antisense transformation caused a high susceptibility to RDV [119-121]. It has also been noted that RDR1 and RDR6 are imperative for secondary CMV vsiRNA genesis in A. thaliana. Further explaining CMV, Quintero et al. [122] employed the bioinformatic approach for the identification of ta-siRNAs and cis-nat-siRNAs in cassava plants from two sRNA libraries constructed by healthy cassava plants and Xanthomonas axonopodis pv. manihotis (Xam) inoculated plants. They identified 54 possible ta-siRNA loci in cassava. Out of these, 15 loci were induced, while the other 39 were repressed in response to Xam infection. Additionally, 15 possible cis-natural antisense transcript (cis-NAT) loci, involved in the production of siRNAs, were also identified from overlapping antisense regions in the genome. All of these were differentially expressing upon Xam infection [122]. RDR1 is needed for vsiRNAs production from the $5^{\prime}$-terminal end of the viral genome, while RDR6 is involved in the vsiRNAs production from the $3^{\prime}$-terminal ends [80]. However, NtRDR1 expression in Nicotiana benthamiana plants, which do not encode RDR1, exhibited the suppression of RNA silencing mediated by RDR6 and enhanced infection in transgenic plants $[123,124]$. Moreover, a high accumulation of HSVd and PSTVd genomic RNAs in $r d r 6$-silenced plants demonstrates the contribution that RDRs make in anti-viroid resistance. Systematic analysis by means of vsiRNA and vdsiRNA profiling in infected plants revealed that sRNAs were processed from pathogen genomic RNAs and declined in $r d r$ knock-out mutants and silenced plants $[94,119,123,125]$. The lessened vsiRNA and vdsiRNA accumulation along with increased susceptibility of $r d r$ mutant plants clearly advocates the anti-viral/viroid function of RDRs. Even though RDR2 is liable for accumulation of $24 \mathrm{nt}$ hc-siRNA, RDR2 mutation exerts little or no effect on vsiRNA accumulation of DNA viruses, e.g., $\mathrm{CalCuV}$ and $\mathrm{CaMV}$ [87]. Tomato Ty-1 and Ty-3, TYLCV resistance genes, encodes RDRs with sequence similarity to $A$. thaliana RDR3, -4 , and -5 . 
The susceptible Lycopersicum lines without these loci witness lower levels of TYLCV vsiRNAs and accrue high viral titers [126-128]. Still in Arabidopsis, the complete antiviral attributes of RDR3, RDR4, and RDR5 have not yet been unveiled. Therefore, there is a dire need to study the function of RDR2 and other RDRs in host-virus/viroid interactions.

The replication and movement of viruses as well as viroids is restricted after vsiRNAs and vdsiRNAs are loaded into AGO proteins. AGO1, AGO2, AGO3, AGO5, AGO7, and AGO10 unite with vsiRNAs or participate in anti-viral RNA silencing pathways [37]. Resurgence from attack with a DNA virus entails the purpose of host AGO4 [129]. As a result, the 24 nt vsiRNAs of DNA viruses may bracket together with AGO4 for methylation of the viral genome. A mutant defective in double-stranded RNA-binding protein (DRB3) interacts with DCL3 and AGO4, shows lower methylation of the viral DNA genome along with greater hyper susceptibility to geminiviruses. It further shows the role that the DCL3-AGO4 RdDM pathway plays in modulating resistance against DNA viruses [130]. Additionally, a novel AGO, i.e., AGO18, is tempted by RSV and maintains rice antiviral resistance [131]. With reference to the vdsiRNAs, 21 and 22 nt vdsiRNAs predominately load into AGO1, AGO2, and AGO3 [37,132]. On the other hand, AGO4, AGO5, and AGO9 become the target of $24 \mathrm{nt}$ vdsiRNAs for loading. AGO6, AGO7, and AGO10 do not bind vdsiRNAs [37]. However, the anti-viroid job of these AGOs needs further investigation.

Contrary to the DCL-based vdsiRNAs processing and loading into plant AGOs, regulation of viroid genomes is still unclear. Transgenic dsRNAs or co-inoculated dsRNAs can be used to silence PSTVd, CEVd, and CChMVd in plants. This silencing is sequence-specific, temperature-dependent, and dose-dependent $[112,133,134]$. Several classes of miRNAs have been discovered that are generated by plants in response to virus and viroid attacks. These play a key role in defense against various viral diseases (Table 1). However, it is evident that viroids may have evolved a mechanism against sRNA silencing. Based on PSTVd and HSVd studies, the viroid circular genome is resistant to RNA silencing [135].

Table 1. The defensive role of various sRNAs against virus and viroid infections.

\begin{tabular}{|c|c|c|c|c|}
\hline sRNAs & Defensive Role in Plant Species & Viruses/Viroids & Target Gene & References \\
\hline $\operatorname{miR} 482$ & Solanum lycopersicum & TCV, CMV, TRV & NBS-LRR & [137] \\
\hline $\mathrm{miR} 6019 / \mathrm{miR} 6020$ & N. tabacum & TMV & $T I R-N B S-L R R$ & [131] \\
\hline miR162 & Arabidopsis & CMV & DCL1 & {$[141,142]$} \\
\hline amiR171 & N. tabacum & CaMV & $2 b$ & [144] \\
\hline amiR-AV1-1 & Tomato & ToLCNDV & $A V 1$ and $A N 2$ & [145] \\
\hline amiR159 & Arabidopsis & TYMV & P69 & [146] \\
\hline amiR159 & Arabidopsis & TuMV & HC-Pro & [146] \\
\hline $\operatorname{miR} 159 a$ & N. benthamiana & PPV & P1/ HC-Pro & [147] \\
\hline miR159a & N. tubacum & PVY & HC-Pro & [150] \\
\hline $\operatorname{miR} 167 b$ & N. tubacum & PVX & TGBp1/p25 & [150] \\
\hline miR171a & N. tubacum & PVX & TGBp1/p25 & [150] \\
\hline Pre-miR159a & S. lycopersicum & CMV & $2 a, 2 b$ & [151] \\
\hline Pre-miR159a & N. benthamiana & WSMoV & $\begin{array}{l}\text { L replicase gene } \\
\text { (Conserved motifs) }\end{array}$ & [152] \\
\hline miR395 & Triticum & WSMV & Conserved region & [153] \\
\hline pre-miR319a & Vitisvinifera & GFLV & Coat protein $(C P)$ & [154] \\
\hline pre-miR169a & N. benthamiana & CLCuBuV & V2 gene & [155] \\
\hline pre-miR319a & S. lycopersicum & ToLCV & $A V 1, A V 2$ & [145] \\
\hline pre-miR168a & S. lycopersicum & ToLCV & $A V 1, A V 2$ & [145] \\
\hline
\end{tabular}


Table 1. Cont.

\begin{tabular}{|c|c|c|c|c|}
\hline sRNAs & Defensive Role in Plant Species & Viruses/Viroids & Target Gene & References \\
\hline pre-miR319a & N. benthamiana & PVY & $C I, N I a, N I b, C P$ & [156] \\
\hline pre-miR159a & Zea mays & RBSDV & Conserved region & [157] \\
\hline pre-miR528 & O. sativa & RSV & Middle segment, 30 end & [159] \\
\hline pre-miR528 & O. sativa & RBSDV & Middle segment, 30 end & [159] \\
\hline pre-miR159a & N. benthamiana & CBSV & $P 1, P 3, C I, N i b$ and $C P$ & [160] \\
\hline Six amiRNAs & N. benthamiana & PSTVd & Structural domains & [162] \\
\hline
\end{tabular}

TuMV: Turnip mosaic virus; TCV: Turnip crinkle virus; CMV: Cucumber mosaic virus; TRV: Tobacco rattle virus; RSV: Rice stripe virus; RDV: Rice dwarf virus; TMV: Tobacco mosaic virus; CaMV: Cauliflower mosaic virus; ToLCNDV: Tomato leaf curl new Dehli virus; TYMV: Turnip yellow mosaic virus; PPV: Plum pox virus; PVX: Potato virus X; PYV: Potato virus Y; WSMoV: Watermelon silver mottle virus; WSMV: Wheat streak mosaic virus; GFLV: Grapevine fanleaf virus; CLCuBuV: Cotton leaf curl Borewala virus; ToLCV: Tomato leaf curl virus; RBSDV: Rice black streaked dwarf virus; WDV: Wheat dwarf virus; CBSV: Cassave brown streak virus; UCBSV: Uganda cassava brown streak virus; TSWV: Tomato spotted wilt virus; PSTVd: Potato spindle tuber viroid.

\section{Plant Small RNAs against Fungal Infections}

With high throughput technology and advancements in bioinformatics, several sRNAs have been identified for their decisive roles in disease development in the case of fungal invasion. sRNAs interplay with multiple classes of disease resistance genes (Table 2) [163,164]. The host sRNAs and their respective targets, either by up- or down-regulation, are involved in disease severity after fungal attack $[49,165,166]$. Conversely, if plants carry the R-gene product, the resistance is administered by the R-Avr interface by holding onto the intrusion of sRNAs [167,168]. Moreover, plant sRNAs regulate homeostasis of plant growth regulators by managing the target transcripts expression $[169,170]$. miR408 is a negative regulator of plantacyanins and laccase [171,172]. Even though the exact role of plantacyanins in plants is mysterious; however, they are supposed to be involved in stress responses cell-to-cell signaling and lignin production [173,174]. Similarly, laccases regulate varied tasks in plants, e.g., lignin synthesis, wound healing, iron acquirement, stress response, and cell wall structure maintenance and veracity $[175,176]$. Therefore, differential regulation of miR408 in wheat cultivars susceptible and resistant to Puccinia graminis f. sp. tritici 2 days after inoculation (DAI) and 10 DAI [177] might result in plantacyanins and laccase-arbitrated perturbations in lignin biosynthesis and HR response. Similarly, miR2118 targets TIR-NBS-LRR Verticillium-dahliae-infected Gossypium hirsutam $[163,178]$. In the same way, pbe-SR23 and pbe-SR3 target TIR-LRR in Populous after Dothiorella gregaria attack $[164,179]$. Osa-miR7695 overexpression resulted in resistance to blast fungus. Os-miR7695-mediated negative regulation of natural resistance-associated macrophage protein 6 (OsNramp6) illustrated a novel regulatory network, integrating miRNA function and mRNA processing in plant immunity [180].

Yin and Li [163] conducted global identification studies of miRNAs and other sRNAs from Gossypium barbadense (Verticillium-tolerant cultivar) and (Gossypium hirsutum cv. Yi-11 (Verticillium-sensitive cultivar). Among 215 miRNAs families, over 65 miRNAs presented modified expression after Verticillium infection in both cotton species. Particularly, three Populous-specific miRNAs (Ptc-miR482, Ptc-miR482-1444, and Ptc-miR482-1448) target the cleavage of PPO (poly phenol oxidase) and R-protein genes regulating plant biotic and abiotic stress tolerance [181]. miR482 and miR1448 down regulation in Verticillium-infected cotton plants displayed amplified PPO and disease resistance proteins. TIR-NBS-LRR, a resistance protein for regulating pathogenesis, is reportedly a target of miR2118 $[178,182]$. The down-regulation of miR2118 shows a higher accumulation of corresponding target proteins, which could be a reason for the high defense response in cotton roots [163]. Chen and coworkers defined 74 conserved miRNA of 37 miRNA families and 27 novel miRNAs in Populus beijingensis infected with D. gregaria [164,183]. Among conserved ones, miR156, miR164, miR159, miR168, miR169, miR172, miR393, miR398, miR396, and miR1447 were up-regulated. Deep sequencing data indicated the 1.2-fold greater expression of conserved miRNA in infected 
plants compared to uninfected plants. This suggests that conserved miRNAs play important roles in defense. Some other miRNAs and siRNA have also been found to be up-regulated after infection with their putative target proteins participating in resistance to disease (Table 2). For example, miRNAs 1447,1448 , and 472 targeted disease resistance proteins and differentially regulated during $D$. gregaria infection [181,184]. In galled loblolly pine stems, miR156 expression was considerably suppressed under the attack of Cronartium quercuum f. sp. fusiforme [185]. Zhao et al. [165] identified pathogen responsive miRNAs in Populus trichocarpa infected with Botryosphaeria dothidea. They found that 41 fungi responsive up-regulated miRNA. Target prediction of these miRNAs indicated their participation in regulating cellular processes, including defense proteins, signaling surges, and metabolic pathways. The fungus responsive miRNAs target many genes at the same time, and each target gene is involved in several biochemical and physiological processes. As a result, the regulation and crosstalk of gene expressions during disease development actively helps to understand disease pathogenesis.

Recently, sRNAs, playing an important role in enhancing immunity against the rice blast disease caused by Magnaporthe oryzae, were uncovered through deep sequencing of sRNA libraries from susceptible and resistant lines in normal conditions [186]. The experimentation revealed that a group of known rice miRNAs were differentially expressing upon $M$. oryzae infection. Furthermore, the real-time reverse transcription-polymerase chain reaction assay showed that the expression of some target genes was negatively correlated with the expression of miRNAs. The results showed that the transgenic rice plants overexpressing miR160a and miR398b embedded an enhanced resistance to $M$. oryzae, as the plants demonstrated decreased fungal growth along with increased hydrogen peroxide accumulation at the infection site and up-regulated expression of defense-related genes [186].

Table 2. The defensive role of various sRNAs against fungal infections.

\begin{tabular}{|c|c|c|c|c|}
\hline Small RNA & $\begin{array}{l}\text { Defensive Role in } \\
\text { Plant Specie }\end{array}$ & Fungus & Target Gene & References \\
\hline tae-miR408 & Wheat & Puccinia striiformis f. sp. tritici & TaCLP1, a type of plantacyanin protein & [187] \\
\hline $\operatorname{miR} 396 a-5 p$ & Solanaceae & P. infestans & GRF & [188] \\
\hline miR5300 & S. lycopersicum & F. oxysporum & Solyc05g008650, tm-2 & [138] \\
\hline $\operatorname{miR396}$ & Arabidopsis & Plectosphaerella cucumerina & GRF & [189] \\
\hline $\operatorname{miR} 396$ & Arabidopsis & Botrytis cinerea & GRF & [189] \\
\hline $\operatorname{miR} 396$ & Arabidopsis & $\begin{array}{l}\text { Fusarium oxysporum } \mathrm{f} . \mathrm{sp} . \\
\text { Conglutinans }\end{array}$ & GRF & [189] \\
\hline $\operatorname{miR} 396$ & Arabidopsis & Colletotrichum higginsianum & $G R F$ & [189] \\
\hline $\operatorname{miR} 160$ & P. trichocarpa & Botryosphaeria dothidea & Auxin response factor, Aux/IAA & {$[165,185]$} \\
\hline $\operatorname{miR} 160$ & Pinustaeda & $\begin{array}{l}\text { Cronartium quercuum } \mathrm{f} \text {. } \\
\text { sp. fusiforme }\end{array}$ & Auxin response factor, $A u x / I A A$ & [190] \\
\hline $\operatorname{miR} 482$ & Cotton & V. dahlia & Disease resistance protein & {$[163,164,181]$} \\
\hline $\operatorname{miR} 1447$ & P. beijingensis & Dothiorella gregaria & Disease resistance protein & {$[163,164]$} \\
\hline $\operatorname{miR} 1448$ & Cotton & V. dahlia & Disease resistance protein & {$[163,164]$} \\
\hline $\operatorname{miR} 1448$ & P. beijingensis & D. gregaria & Glutathione & [165] \\
\hline $\operatorname{miR} 1448$ & P. trichocarpa & B. dothidea & $\begin{array}{c}\text { S-conjugate, ABC transporter, } \\
\text { ATP-binding cassette transport protein }\end{array}$ & [181] \\
\hline $\operatorname{miR} 1450$ & P. trichocarpa & B. dothidea & Leucine-rich repeat & [165] \\
\hline $\operatorname{miR} 2118$ & Cotton & V. dahlia & TIR-NBS-LRR & [163] \\
\hline Pbe-SR3 & P. beijingensis & D. gregaria & Leucine Rich Repeat & [164] \\
\hline Pbe-SR23 & P. beijingensis & D. gregaria & Leucine Rich Repeat, NB-ARC domain & [164] \\
\hline Pbe-SR25 & P. beijingensis & D. gregaria & FtsH Extracellular & [164] \\
\hline
\end{tabular}

The unique expression pattern of miRNAs in the same family corresponds with their diverse functions in dissimilar species under different types of pathogen. Hence, to develop a comprehensive understanding of the regulatory functions of miRNAs and their target genes during pathogen attack, intense experimental validation of miRNAs are mandatory. For example, the miR1138 accumulation in infected wheat plants suggests that fungus perturbs the cell function homeostasis by modulating host protein biosynthetic machinery. In the presence of the $S r 24$ gene, the expression of miRNAs decreased significantly depicting the R-gene mediated defense response and thus disease resistance [177,179]. Up or down-regulation of miRNA in the genotype having R-gene suggests interaction of miRNA with R-gene in disease signaling. In powdery mildew disease, the down-regulation of miR156, miR159, 
miR164, and miR168 suggests the up-regulation of corresponding target genes involved in signal transduction, stress response, root development, and oxidative stress response (Table 3).

Table 3. Unknown sRNAs that are involved in the defensive role against fungal infections.

\begin{tabular}{|c|c|c|c|c|}
\hline Small RNA & $\begin{array}{l}\text { Defensive Role in } \\
\text { Plant Specie }\end{array}$ & Fungus & Target Gene & References \\
\hline Unknown & S. lycopersicum & F. oxysporum & Solyc08g075630, Solyc08 g076000 & [138] \\
\hline Unknown & S. lycopersicum & F. oxysporum & Solyc05g008650, tm-2 & [138] \\
\hline Unknown & Wheat & P. striiformis f. sp. Tritici & TaCLP1, a type of plantacyanin protein & [187] \\
\hline Unknown & Gossypium raimondii & V. dahlia & NBS-LRR & [137] \\
\hline Unknown & Morchella esculenta & Colletotrichum gloeosporioides & ARF10 & [191] \\
\hline Unknown & O. sativa & Magnaporthe oryzae & $\begin{array}{l}\text { ARF16 and aB3 DNA-binding } \\
\text { domain-containing protein }\end{array}$ & [12] \\
\hline Unknown & M. esculenta & C. gloeosporioides & TIR1 & [191] \\
\hline Unknown & Hordeum vulgare $L$. & $\begin{array}{c}\text { Blumeria graminis f. sp. } \\
\text { Hordei }\end{array}$ & SOD1 & [192] \\
\hline Unknown & O. sativa & M. oryzae & SOD2 & [12] \\
\hline Unknown & M. esculenta & C. gloeosporioides & ARF10 & [191] \\
\hline
\end{tabular}

\section{Plant Small RNAs against Bacterial Infections}

Plant sRNAs directly take part in responses to bacterial diseases (Table 4). The first identified sRNAs involved in plant immunity against bacterial infections were miRNAs. Bacterially infected plants exhibited several changes in miRNA accumulation and functioning, especially in auxin-signaling-associated miRNAs [54,193]. PAMP flagellin perception in A. thaliana restricted P. syringae invasion. However, no mechanism involved in triggering resistance is on record. Navarro et al. [194] observed the targets of miR393 with the help of gene expression profiles analysis in seedlings challenged with flg22. TIR1, AFB2, AFB3 (the three auxin receptor transcripts) accumulation was suppressed upon flg22 treatment. However, AFB1 was not perturbed, perhaps due to a somewhat dissimilar miR393-binding site. When the miR393-resistant auxin receptor AFB1-Myc was overexpressed in a tir1-1 background, it enhanced disease susceptibility in Arabidopsis. The results suggested that miR393 was involved in controlling defense responses against $P$. syringae. Advanced experiments substantiated this role for miR393a. Overexpression of miR393a augmented plant resistance and trimmed down virulent $P$. syringae pv. tomato (Pst) DC3000 growth [194]. Captivatingly, both virulent and avirulent $P$. syringae strains harboring the type III effector protein, i.e., avrRpt2, demonstrated similar growth under the AFB1-Myc-overexpressing Arabidopsis. Accumulation of miR393 has also been reportedly induced in Agrobacterium tumefaciens infiltration. Fascinatingly, the flg22 of $A$. tumefaciens, completely inactive to the receptor kinase FLS2 as a ligand, maintained miR393 expression levels without significant alterations $[4,195,196]$. Collectively, these results imply that miR393a is strongly involved in ETI and, most importantly, that repression of auxin signaling constitutes a plants defense response to bacterial infection.

Table 4. The defensive role of various sRNAs against bacterial infections.

\begin{tabular}{ccccc}
\hline Small RNA & $\begin{array}{l}\text { Defensive Role } \\
\text { in Plant Specie }\end{array}$ & Bacteria & Target Gene & References \\
\hline miR159 & Arabidopsis & P. syringae & MYB33 & {$[197]$} \\
miR159 & Arabidopsis & P. syringae & MYB65 & {$[197]$} \\
miR159 & Arabidopsis & P. syringae & MYC101 & {$[197]$} \\
miR160 & Arabidopsis & P. syringae & ARF10 & {$[198]$} \\
miR160 & Arabidopsis & P. syringae & ARF17 & {$[198]$} \\
miR160 & Arabidopsis & P. syringae & \\
\hline
\end{tabular}


Table 4. Cont.

\begin{tabular}{|c|c|c|c|c|}
\hline Small RNA & $\begin{array}{l}\text { Defensive Role } \\
\text { in Plant Specie }\end{array}$ & Bacteria & Target Gene & References \\
\hline miR167 & Arabidopsis & P. syringae & ARF8 & [199] \\
\hline $\operatorname{miR} 167$ & Arabidopsis & P. syringae & ARF6 & [197] \\
\hline miR393 & Arabidopsis & P. syringae & TIR1 & [194] \\
\hline miR393 & Arabidopsis & P. syringae & $A F B 2$ & [199] \\
\hline miR393 & Arabidopsis & P. syringae & AFB3 & [199] \\
\hline $\operatorname{miR} 393 b$ & Arabidopsis & P. syringae & MEMB12 & {$[58]$} \\
\hline $\operatorname{miR} 393 b$ & N. benthamiana & P. syringae & MEMB12 & [58] \\
\hline miR399 & Citrus & $\begin{array}{l}\text { Candidatus liberibacter. } \\
\text { asiaticus }\end{array}$ & PHO2 & [200] \\
\hline $\operatorname{miR} 408$ & Arabidopsis & P. syringae & $\begin{array}{c}\text { Copper protein plantacyanin and copper } \\
\text { ion binding protein genes }\end{array}$ & [197] \\
\hline $\operatorname{miR} 825$ & Arabidopsis & P. syringae & $\begin{array}{l}\text { Remorin, zinc finger homebox family, } \\
\text { frataxin-related }\end{array}$ & [199] \\
\hline $\begin{array}{l}\text { nat-siRNA } \\
\text {-ATGB2 }\end{array}$ & Arabidopsis & P. syringae & $P P R L$ & [62] \\
\hline AtlsiRNA-1 & Arabidopsis & P. syringae & AtRAP & {$[56]$} \\
\hline miR390 & Arabidopsis & P. syringae & TAS3 & [197] \\
\hline $\operatorname{miR} 398$ & Arabidopsis & P. syringae & COX5b.1 & [182] \\
\hline $\operatorname{miR398}$ & Arabidopsis & P. syringae & CSD1 & [198] \\
\hline $\operatorname{miR} 398$ & Arabidopsis & P. syringae & CSD2 & [198] \\
\hline $\operatorname{miR} 408$ & Arabidopsis & P. syringae & $\begin{array}{l}\text { Copper protein plantacyanin, laccase } \\
\text { copper protein and copper ion binding } \\
\text { protein genes (predicted targets) }\end{array}$ & [197] \\
\hline $\operatorname{miR773}$ & Arabidopsis & P. syringae & MET2 & [198] \\
\hline $\operatorname{miR} 472$ & Arabidopsis & P. syringae & CC-NBS-LRR & [201] \\
\hline
\end{tabular}

High-throughput sequencing analyses support the up-regulated miR393 during plant-bacteria interactions [199,202-204]. Other than miR393, induction of sRNAs such as miR160 and miR167 has been observed after the inoculation of non-pathogenic Pst DC3000 $\mathrm{hrCC}^{-}$and flg22. Surprisingly, treatment with flg22 did not presented a major drop of miR167 targets i.e., ARF8 and ARF6, in contrast to the down-regulation of miR160 targets e.g., ARF10, ARF16, and ARF17. miR160a-overexpressing plants increased callose deposition after treatment with flg22 and $h r c C^{-}$ mutant bacteria. Nevertheless, in plants overexpressing miR160, resistance to Pst DC3000 bacteria proliferation remained unaffected [61,198,205].

The accumulation of hormone-associated miRNAs contributes to plant defense, and the down-regulation of certain miRNAs influences plant immunity $[48,61,198]$. For instance, miR398, which is responsible for targeting copper superoxide dismutases (CSD1,CSD2) and a cytochrome $\mathrm{c}$ oxidase subunit V (COX5), is lessened in plants facing avirulent strains like Pst DC3000 avrRpm1 and Pst DC3000 avrRpt2 [182]. miR398 accumulation is also altered by abiotic as well as biotic stresses e.g., salinity, increased light, metals, ozone stress, and flg22 treatment [182,198,206]. During biotic and abiotic stresses, plants experience an accumulation of ROS in the infection site. Superoxide dismutases (SODs) convert superoxide into oxygen and hydrogen peroxide and therefore regulate ROS [1,207]. Expression of miR398 is reduced in oxidative stress, promoting accumulation of CSD1 and CSD2 [30,206]. In agreement with expression analyses under different stresses, overexpressing miR398 curtailed callose deposition after infection, i.e., flg22, Pst DC3000 $\mathrm{hrC}^{-}$. Moreover, these transgenic plants appeared more sensitive to virulent and avirulent strains of P. syringae after CSD1, CSD2, and COX5 gene silencing [198]. Such observations confirmed a connection between the miR398 family and the miRNA-mediated plant defense responses.

miR773 takes part in PTI $[198,208]$. mRNA coding DMT2 (DNA methyltransferase 2) is targeted by miR773. Crane and Gelvin [209] observed less tumor formation after silencing the DMT2 gene during infection due to Agrobacterium. Deep sequencing analysis highlighted hampered miR773 accumulation after flg22 treatment. Accordingly, DMT2 accumulation was induced against flg22 treatment. miR773-overexpressing transgenic plants had low methyltransferase 2 (MET2) mRNA 
levels, curtailed callose deposition, and high susceptibility to bacterial infections. Reduction of miR398 and miR773 under biotic stress points out a negative regulation of PTI [61,198,208].

In sRNA-based plant immune response, the starred strand of miR393* also functions in plant defense $[151,210]$. In A. thaliana, AGO2 had been induced after P. syringae attack. After Pst avrRpt2 treatment, star strand e.g., miR393* was noticeably loaded into AGO2. Among predicted targets for miR393, a validated target that functions in vesicle transport is Golgi-localized SNARE protein, i.e., MEMB12. The MEMB12 knockout mutants demonstrated augmented immunity to both avirulent and virulent strains of $P$. syringae. The plant secretory machinery is designated as vital machinery in plant-microbe interactions due to the secretion of antimicrobial proteins and several other biomolecules. During loss-of-function studies involving MEMB12, main antimicrobial PR protein i.e., PR1 was highly secreted. This finding proposes improved resistance due to mutant memb12 as a consequence of PR proteins secretion and accumulation. As expected, miR393* overexpression also displayed increased disease resistance to Pst avrRpt2 and high secretion and accumulation PR1 protein [151]. Despite considerable work regarding identification of miRNAs in plant defense, there are still a large number of sRNAs that pose confusion and are still unknown but, expectedly, play a key role in plant defense against fungal infections (Table 3).

siRNAs, like miRNAs, enhance gene expression reorganization in plant defense responses. These sRNAs are induced against pathogens and are involved in triggering resistance to diseases. siRNAs that are involved in plant immunity include nat-siRNA, nat-siRNAATGB2, and the bacteria-induced long siRNAs, mainly AtlsiRNA-1 [50,53,56,62]. Five lsiRNAs are induced against $P_{s t}$ (avrRpt2) infection [56]. AtlsiRNA-1 is the most functionally characterized lsiRNA. This is generated from the overlapping region of the $S R R L K$ (putative leucine-rich repeat receptor-like protein kinase) AtlsiRNA- 1 is complementary to the $3^{\prime}$ UTR of the antisense gene AtRAP. In mutant AtRAP, plants reduced virulent and avirulent $P$ st growth was observed. This suggests that the role of a negative regulator in plant resistance responses. Based on such findings, it can be concluded that AtlsiRNA-1 may promote resistance against Pst avrRpt2 infection due to the particular regulation of its target. However, the role of siRNAs in plant immunity during bacterial infections, in connection with the knowledge generated by other sRNAs, may highlight other sRNA-regulating bacteria stress responses.

\section{Plant Small RNAs against Nematode Infections}

Silencing parasitism or housekeeping-involved genes in nematode-mediated plant diseases may alter the expression of sRNA and modulate resistance to the nematode attack [49,211-213]. Sindhu et al. [214] studied four parasitism-involved genes for Heterodera schachtii. Studying different RNAi lines revealed that incomplete resistance was achieved, but the number of nematode females decreased by 23-64\%. Ibrahim et al. [215] achieved reduction in the Meloidogyne incognita gall formation in soybean roots by suppressing the tyrosine phosphatase (TP) genes.

miRNAs also take part in plant-nematode interactions. Against the nematode, $H$. schachtii, different miRNAs were down-regulated, e.g., miR161, miR164, miR167a, miR172c, miR396c, miR396a,b, and miR398a [216,217]. Comparative miRNA profiling in G. max exhibited 101 miRNAs responsive to the infection of the most destructive soybean cyst nematode (SCN). Furthermore, 20 differentially expressed miRNAs were observed in SCN-resistant and susceptible G. max varieties [218]. Besides, nematode-induced miRNAs and sRNAs seemingly participate in the establishment and parasitism of feeding sites, respectively [216]. Overexpression of nematode-induced miRNAs, and/or silencing of their corresponding targets, may offer significant information about plant-nematode parasitism and lead to the development of crop plants with nematode resistance.

\section{Conclusions and Future Prospects}

The implication of sRNAs in controlling plant immunity and coping with virulent pathogens urges researchers to take advantage of RNA silencing machinery in terms of amplified plant immunity against diseases. Although substantial efforts are being performed globally to recognize the protection purpose 
of plant sRNAs, the exact anti-pathogenic defense part of their function is unclear. Similarly, siRNAs are not receiving the attention that is due for their function in anti-microbial immunity. It is also known that pathogens have improved their virulence by developing sRNAs. Hence, focusing virulence development and unraveling pathogen sRNAs with susceptible plant targets can assist in decoding plant-pathogen interactions. Likewise, investigation into missing links about infection-mediated sRNAs production and their fast removal can be very beneficial. We expect that further research upon sRNA-mediated plant defense against different diseases, by achieving disease resistance, will help us enhance global food security.

Acknowledgments: We thank Huang Wei for assistance in all the official activities regarding this project. The study was funded by the Fujian Agriculture and Forestry University, research grant No. CXZX2017211.

Conflicts of Interest: The authors declare no conflict of interest.

\section{References}

1. Ali, Q.; Daud, M.K.; Haider, M.Z.; Ali, S.; Rizwan, M.; Aslam, N.; Noman, A.; Iqbal, N.; Shahzad, F.; Deeba, F. Seed priming by sodium nitroprusside improves salt tolerance in wheat (Triticum aestivum $\mathrm{L}$.) by enhancing physiological and biochemical parameters. Plant Physiol. Biochem. 2017, 119, 50-58. [PubMed]

2. Bebber, D.P.; Gurr, S.J. Crop-destroying fungal and oomycete pathogens challenge food security. Fungal Genet. Biol. 2015, 74, 62-64. [PubMed]

3. Liu, Z.; Shi, L.; Yang, S.; Lin, Y.; Weng, Y.; Li, X.; Hussain, A.; Noman, A.; He, S. Functional and Promoter Analysis of ChiIV3, a Chitinase of Pepper Plant, in Response to Phytophthora capsici Infection. Int. J. Mol. Sci. 2017, 18, 1661. [CrossRef] [PubMed]

4. Huot, B.; Yao, J.; Montgomery, B.L.; He, S.Y. Growth-defense tradeoffs in plants: A balancing act to optimize fitness. Mol. Plant 2014, 7, 1267-1287. [CrossRef] [PubMed]

5. Noman, A.; Fahad, S.; Aqeel, M.; Ali, U.; Anwar, S.; Baloch, S.K.; Zainab, M. miRNAs: Major modulators for crop growth and development under abiotic stresses. Biotechnol. Lett. 2017, 39, 685-700. [PubMed]

6. Zaynab, M.; Kanwal, S.; Hussain, I.; Qasim, M.; Noman, A.; Iqbal, U.; Ali, G.M.; Bahadar, K.; Jamil, A.; Sughra, K.; et al. Rice chitinase gene expression in genetically engineered potato confers resistance against Fusarium solani and Rhizictonia solani. PSM Microbiol. 2017, 2, 63-73.

7. Santoni, G.; Cardinali, C.; Morelli, M.B.; Santoni, M.; Nabissi, M.; Amantini, C. Danger-and pathogen-associated molecular patterns recognition by pattern-recognition receptors and ion channels of the transient receptor potential family triggers the inflammasome activation in immune cells and sensory neurons. J. Neuroinflammation 2015, 12, 21. [CrossRef] [PubMed]

8. Liston, A.; Masters, S.L. Homeostasis-altering molecular processes as mechanisms of inflammasome activation. Nat. Rev. Immunol. 2017, 17, 208-214. [PubMed]

9. Dana, H.; Chalbatani, G.M.; Mahmoodzadeh, H.; Karimloo, R.; Rezaiean, O.; Moradzadeh, A.; Mehmandoost, N.; Moazzen, F.; Mazraeh, A.; Marmari, V. Molecular Mechanisms and Biological Functions of siRNA. Int. J. Biomed. Sci. 2017, 13, 48. [PubMed]

10. Park, C.-J.; Caddell, D.F.; Ronald, P.C. Protein phosphorylation in plant immunity: Insights into the regulation of pattern recognition receptor-mediated signaling. Front. Plant Sci. 2012, 3, 177. [CrossRef] [PubMed]

11. Newman, M.-A.; Sundelin, T.; Nielsen, J.T.; Erbs, G. MAMP (microbe-associated molecular pattern) triggered immunity in plants. Front. Plant Sci. 2013, 4, 139. [CrossRef] [PubMed]

12. Li, B.; Lu, D.; Shan, L. Ubiquitination of pattern recognition receptors in plant innate immunity. Mol. Plant Pathol. 2014, 15, 737-746. [CrossRef] [PubMed]

13. Trdá, L.; Boutrot, F.; Claverie, J.; Brulé, D.; Dorey, S.; Poinssot, B. Perception of pathogenic or beneficial bacteria and their evasion of host immunity: Pattern recognition receptors in the frontline. Front. Plant Sci. 2015, 6, 219. [CrossRef] [PubMed]

14. Jwa, N.-S.; Hwang, B.K. Convergent evolution of pathogen effectors toward reactive oxygen species signaling networks in plants. Front. Plant Sci. 2017, 8, 1687. [CrossRef] [PubMed]

15. Withers, J.; Dong, X. Post-translational regulation of plant immunity. Curr. Opin. Plant Biol. 2017, 38, 124-132. [CrossRef] [PubMed] 
16. De Wit, P.J.G.M. Cladosporium fulvum effectors: Weapons in the arms race with tomato. Annu. Rev. Phytopathol. 2016, 54, 1-23. [CrossRef] [PubMed]

17. Gouveia, B.C.; Calil, I.P.; Machado, J.P.B.; Santos, A.A.; Fontes, E.P. Immune receptors and co-receptors in antiviral innate immunity in plants. Front. Microbiol. 2017, 7, 2139. [CrossRef] [PubMed]

18. Schuebel, F.; Rocker, A.; Edelmann, D.; Schessner, J.; Brieke, C.; Meinhart, A. 3'-NADP and 3'-NAADP, Two Metabolites Formed by the Bacterial Type III Effector AvrRxo1. J. Biol. Chem. 2016, 291, 22868-22880. [CrossRef] [PubMed]

19. Kushalappa, A.C.; Yogendra, K.N.; Karre, S. Plant innate immune response: Qualitative and quantitative resistance. Crit. Rev. Plant Sci. 2016, 35, 38-55. [CrossRef]

20. Bashir, Z.; Ahmad, A.; Shafique, S.; Anjum, T.; Shafique, S.; Akram, W. Hypersensitive response-A biophysical phenomenon of producers. Eur. J. Microbiol. Immunol. 2013, 3, 105-110. [CrossRef] [PubMed]

21. Bigeard, J.; Colcombet, J.; Hirt, H. Signaling mechanisms in pattern-triggered immunity (PTI). Mol. Plant 2015, 8, 521-539. [CrossRef] [PubMed]

22. Fawke, S.; Doumane, M.; Schornack, S. Oomycete interactions with plants: Infection strategies and resistance principles. Microbiol. Mol. Biol. Rev. 2015, 79, 263-280. [CrossRef] [PubMed]

23. Henry, E.; Toruño, T.Y.; Jauneau, A.; Deslandes, L.; Coaker, G.L. Direct and indirect visualization of bacterial effector delivery into diverse plant cell types during infection. Plant Cell 2017, 29, 1555. [CrossRef] [PubMed]

24. Patil, V.S.; Zhou, R.; Rana, T.M. Gene regulation by non-coding RNAs. Crit. Rev. Biochem. Mol. Biol. 2014, 49, 16-32. [CrossRef] [PubMed]

25. Liu, X.; Hao, L.; Li, D.; Zhu, L.; Hu, S. Long non-coding RNAs and their biological roles in plants. Genom. Proteom. Bioinform. 2015, 13, 137-147. [CrossRef] [PubMed]

26. Islam, W.; Zaynab, M.; Qasim, M.; Wu, Z. Plant-virus interactions: Disease resistance in focus. Hosts Viruses 2017, 4, 5-20.

27. MacFarlane, L.-A.; Murphy, P.R. MicroRNA: Biogenesis, function and role in cancer. Curr. Genom. 2010, 11, 537-561. [CrossRef] [PubMed]

28. Felekkis, K.; Touvana, E.; Stefanou, C.; Deltas, C. microRNAs: A newly described class of encoded molecules that play a role in health and disease. Hippokratia 2010, 14, 236. [PubMed]

29. Rolle, K.; Piwecka, M.; Belter, A.; Wawrzyniak, D.; Jeleniewicz, J.; Barciszewska, M.Z.; Barciszewski, J. The sequence and structure determine the function of mature human miRNAs. PLoS ONE 2016, 11, e0151246. [CrossRef] [PubMed]

30. Noman, A.; Aqeel, M. miRNA-based heavy metal homeostasis and plant growth. Environ. Sci. Pollut. Res. 2017, 24, 10068-10082. [CrossRef] [PubMed]

31. Noman, A.; Aqeel, M.; Deng, J.; Khalid, N.; Sanaullah, T.; Shuilin, H. Biotechnological Advancements for Improving Floral Attributes in Ornamental Plants. Front. Plant Sci. 2017, 8, 530. [CrossRef] [PubMed]

32. Achkar, N.P.; Cambiagno, D.A.; Manavella, P.A. miRNA biogenesis: A dynamic pathway. Trends Plant Sci. 2016, 21, 1034-1044. [CrossRef] [PubMed]

33. Cui, J.; You, C.; Chen, X. The evolution of microRNAs in plants. Curr. Opin. Plant Biol. 2017, 35, 61-67. [CrossRef] [PubMed]

34. D'Ario, M.; Griffiths-Jones, S.; Kim, M. Small RNAs: Big impact on plant development. Trends Plant Sci. 2017, 22, 1056-1068. [CrossRef] [PubMed]

35. Katiyar-Agarwal, S.; Jin, H. Role of small RNAs in host-microbe interactions. Annu. Rev. Phytopathol. 2010, 48, 225-246. [CrossRef] [PubMed]

36. Devert, A.; Fabre, N.; Floris, M.; Canard, B.; Robaglia, C.; Crété, P. Primer-dependent and primer-independent initiation of double stranded RNA synthesis by purified Arabidopsis RNA-dependent RNA polymerases RDR2 and RDR6. PLoS ONE 2015, 10, e0120100. [CrossRef] [PubMed]

37. Huang, J.; Yang, M.; Lu, L.; Zhang, X. Diverse functions of small RNAs in different plant-pathogen communications. Front. Microbiol. 2016, 7, 1552. [CrossRef] [PubMed]

38. Méndez, C.; Ahlenstiel, C.L.; Kelleher, A.D. Post-transcriptional gene silencing, transcriptional gene silencing and human immunodeficiency virus. World J. Virol. 2015, 4, 219-244. [CrossRef] [PubMed]

39. Martienssen, R.; Moazed, D. RNAi and heterochromatin assembly. Cold Spring Harbor Perspect. Biol. 2015, 7, a019323. [CrossRef] [PubMed] 
40. Moazed, D. Small RNAs in transcriptional gene silencing and genome defence. Nature 2009, 457, 413-420. [CrossRef] [PubMed]

41. Sampey, G.C.; Guendel, I.; Das, R.; Jaworski, E.; Klase, Z.; Narayanan, A.; Kehn-Hall, K.; Kashanchi, F. Transcriptional gene silencing (TGS) via the RNAi machinery in HIV-1 infections. Biology 2012, 1, 339-369. [CrossRef] [PubMed]

42. Guleria, P.; Mahajan, M.; Bhardwaj, J.; Yadav, S.K. Plant small RNAs: Biogenesis, mode of action and their roles in abiotic stresses. Genom. Proteom. Bioinform. 2011, 9, 183-199. [CrossRef]

43. Zhang, C.; Wu, Z.; Li, Y.; Wu, J. Biogenesis, function, and applications of virus-derived small RNAs in plants. Front. Microbiol. 2015, 6, 1237. [CrossRef] [PubMed]

44. Bloch, S.; Wegrzyn, A.; Węgrzyn, G.; Nejman-Faleńczyk, B. Small and Smaller-sRNAs and MicroRNAs in the Regulation of Toxin Gene Expression in Prokaryotic Cells: A Mini-Review. Toxins 2017, 9, 181. [CrossRef] [PubMed]

45. Tripp, V.; Martin, R.; Orell, A.; Alkhnbashi, O.S.; Backofen, R.; Randau, L. Plasticity of archaeal C/D box sRNA biogenesis. Mol. Microbiol. 2017, 103, 151-164. [CrossRef] [PubMed]

46. Yu, D.; Ma, X.; Zuo, Z.; Shao, W.; Wang, H.; Meng, Y. Bioinformatics resources for deciphering the biogenesis and action pathways of plant small RNAs. Rice 2017, 10, 38. [CrossRef] [PubMed]

47. Yu, Q.; Liu, Y.; Li, M.; Yu, B. Small RNA biogenesis and degradation in plants. In Plant Epigenetics; Springer: Berlin/Heidelberg, Germany, 2017; pp. 107-127.

48. Seo, J.-K.; Wu, J.; Lii, Y.; Li, Y.; Jin, H. Contribution of small RNA pathway components in plant immunity. Mol. Plant-Microbe Interact. 2013, 26, 617-625. [CrossRef] [PubMed]

49. Kamthan, A.; Chaudhuri, A.; Kamthan, M.; Datta, A. Small RNAs in plants: Recent development and application for crop improvement. Front. Plant Sci. 2015, 6, 208. [CrossRef] [PubMed]

50. Weiberg, A.; Jin, H. Small RNAs-the secret agents in the plant-pathogen interactions. Curr. Opin. Plant Biol. 2015, 26, 87-94. [CrossRef] [PubMed]

51. Wang, H.L.V.; Chekanova, J.A. Small RNAs: Essential regulators of gene expression and defenses against environmental stresses in plants. Wiley Interdiscip. Rev. RNA 2016, 7, 356-381. [CrossRef] [PubMed]

52. Martinez, G.; Köhler, C. Role of small RNAs in epigenetic reprogramming during plant sexual reproduction. Curr. Opin. Plant Biol. 2017, 36, 22-28. [CrossRef] [PubMed]

53. Islam, W.; Islam, S.u.; Qasim, M.; Wang, L. Host-Pathogen interactions modulated by small RNAs. RNA Biol. 2017, 14, 891-904. [CrossRef] [PubMed]

54. Zhang, C.; Ding, Z.; Wu, K.; Yang, L.; Li, Y.; Yang, Z.; Shi, S.; Liu, X.; Zhao, S.; Yang, Z. Suppression of jasmonic acid-mediated defense by viral-inducible MicroRNA319 facilitates virus infection in rice. Mol. Plant 2016, 9, 1302-1314. [CrossRef] [PubMed]

55. Weiberg, A.; Wang, M.; Lin, F.-M.; Zhao, H.; Zhang, Z.; Kaloshian, I.; Huang, H.-D.; Jin, H. Fungal small RNAs suppress plant immunity by hijacking host RNA interference pathways. Science 2013, 342, 118-123. [CrossRef] [PubMed]

56. Katiyar-Agarwal, S.; Gao, S.; Vivian-Smith, A.; Jin, H. A novel class of bacteria-induced small RNAs in Arabidopsis. Genes Dev. 2007, 21, 3123-3134. [CrossRef] [PubMed]

57. Nicaise, V. Crop immunity against viruses: Outcomes and future challenges. Front. Plant Sci. 2014, 5, 660. [CrossRef] [PubMed]

58. Zhang, X.; Li, H.; Zhang, J.; Zhang, C.; Gong, P.; Ziaf, K.; Xiao, F.; Ye, Z. Expression of artificial microRNAs in tomato confers efficient and stable virus resistance in a cell-autonomous manner. Transgenic Res. 2011, 20, 569-581. [CrossRef] [PubMed]

59. Zvereva, A.S.; Pooggin, M.M. Silencing and innate immunity in plant defense against viral and non-viral pathogens. Viruses 2012, 4, 2578-2597. [CrossRef] [PubMed]

60. Ellendorff, U.; Fradin, E.F.; de Jonge, R.; Thomma, B.P.H.J. RNA silencing is required for Arabidopsis defence against Verticillium wilt disease. J. Exp. Bot. 2008, 60, 591-602. [CrossRef] [PubMed]

61. Peláez, P.; Sanchez, F. Small RNAs in plant defense responses during viral and bacterial interactions: Similarities and differences. Front. Plant Sci. 2013, 4, 343. [CrossRef] [PubMed]

62. Katiyar-Agarwal, S.; Morgan, R.; Dahlbeck, D.; Borsani, O.; Villegas, A.; Zhu, J.-K.; Staskawicz, B.J.; Jin, H. A pathogen-inducible endogenous siRNA in plant immunity. Proc. Natl. Acad. Sci. USA 2006, 103, 18002-18007. [CrossRef] [PubMed] 
63. Matzke, M.A.; Mosher, R.A. RNA-directed DNA methylation: An epigenetic pathway of increasing complexity. Nat. Rev. Genet. 2014, 15, 394-408. [CrossRef] [PubMed]

64. López Sánchez, A.; Stassen, J.H.; Furci, L.; Smith, L.M.; Ton, J. The role of DNA (de) methylation in immune responsiveness of Arabidopsis. Plant J. 2016, 88, 361-374. [CrossRef] [PubMed]

65. Le, T.-N.; Schumann, U.; Smith, N.A.; Tiwari, S.; Au, P.C.K.; Zhu, Q.-H.; Taylor, J.M.; Kazan, K.; Llewellyn, D.J.; Zhang, R. DNA demethylases target promoter transposable elements to positively regulate stress responsive genes in Arabidopsis. Genome Biol. 2014, 15, 458. [CrossRef] [PubMed]

66. Dowen, R.H.; Pelizzola, M.; Schmitz, R.J.; Lister, R.; Dowen, J.M.; Nery, J.R.; Dixon, J.E.; Ecker, J.R. Widespread dynamic DNA methylation in response to biotic stress. Proc. Natl. Acad. Sci. USA 2012, 109, E2183-E2191. [CrossRef] [PubMed]

67. Yu, A.; Lepère, G.; Jay, F.; Wang, J.; Bapaume, L.; Wang, Y.; Abraham, A.-L.; Penterman, J.; Fischer, R.L.; Voinnet, O. Dynamics and biological relevance of DNA demethylation in Arabidopsis antibacterial defense. Proc. Natl. Acad. Sci. USA 2013, 110, 2389-2394. [CrossRef] [PubMed]

68. López, A.; Ramírez, V.; García-Andrade, J.; Flors, V.; Vera, P. The RNA silencing enzyme RNA polymerase V is required for plant immunity. PLoS Genet. 2011, 7, e1002434. [CrossRef] [PubMed]

69. Islam, W.; Zhang, J.; Adnan, M.; Noman, A.; Zainab, M.; Jian, W. Plant virus ecology: A glimpse of recent accomplishments. Appl. Ecol. Environ. Res. 2017, 15, 691-705. [CrossRef]

70. Arif, M.; Lin, W.; Lin, L.; Islam, W.; Jie, Z.; He, Z.; Du, Z.; Wu, Z. Cotton leaf curl Multan virus infecting Hibiscus sabdariffa in China. Can. J. Plant Pathol. 2017, 1-4. [CrossRef]

71. Islam, W.; Wu, Z. Genetic Defense Approaches against Begomoviruses. J. Appl. Virol. 2017, 6, 26-49. [CrossRef]

72. Hamilton, A.J.; Baulcombe, D.C. A species of small antisense RNA in posttranscriptional gene silencing in plants. Science 1999, 286, 950-952. [CrossRef] [PubMed]

73. Zhao, J.; Liu, Q.; Hu, P.; Jia, Q.; Liu, N.; Yin, K.; Cheng, Y.; Yan, F.; Chen, J.; Liu, Y. An efficient Potato virus X-based microRNA silencing in Nicotiana benthamiana. Sci. Rep. 2016, 6, 20573. [CrossRef] [PubMed]

74. Ding, B. The biology of viroid-host interactions. Annu. Rev. Phytopathol. 2009, 47, 105-131. [CrossRef] [PubMed]

75. Islam, W. Management of plant virus diseases; farmer's knowledge and our suggestions. Hosts Viruses 2017, 4, 28-33.

76. Islam, W.; Adnan, M.; Tayyab, M.; Hussain, M.; Islam, S.U. Phyto-metabolites; An Impregnable Shield against Plant Viruses. Nat. Prod. Commun. 2018, 13, 105-112.

77. Pooggin, M.M. RNAi-mediated resistance to viruses: A critical assessment of methodologies. Curr. Opin. Virol. 2017, 26, 28-35. [CrossRef] [PubMed]

78. Yoo, B.-C.; Kragler, F.; Varkonyi-Gasic, E.; Haywood, V.; Archer-Evans, S.; Lee, Y.M.; Lough, T.J.; Lucas, W.J. A systemic small RNA signaling system in plants. Plant Cell 2004, 16, 1979-2000. [CrossRef] [PubMed]

79. Donaire, L.; Wang, Y.; Gonzalez-Ibeas, D.; Mayer, K.F.; Aranda, M.A.; Llave, C. Deep-sequencing of plant viral small RNAs reveals effective and widespread targeting of viral genomes. Virology 2009, 392, 203-214. [CrossRef] [PubMed]

80. Wang, X.-B.; Wu, Q.; Ito, T.; Cillo, F.; Li, W.-X.; Chen, X.; Yu, J.-L.; Ding, S.-W. RNAi-mediated viral immunity requires amplification of virus-derived siRNAs in Arabidopsis thaliana. Proc. Natl. Acad. Sci. USA 2010, 107, 484-489. [CrossRef] [PubMed]

81. Li, J.; Zheng, H.; Zhang, C.; Han, K.; Wang, S.; Peng, J.; Lu, Y.; Zhao, J.; Xu, P.; Wu, X. Different Virus-Derived siRNAs Profiles between Leaves and Fruits in Cucumber Green Mottle Mosaic Virus-Infected Lagenaria siceraria Plants. Front. Microbiol. 2016, 7, 1797. [CrossRef] [PubMed]

82. Miao, B.; YANG, G.-S.; CHEN, W.-T.; LIN, R.-M.; Jian, L.; MAO, Z.-C.; XIE, B.-Y. Characterization and function of Tomato yellow leaf curl virus-derived small RNAs generated in tolerant and susceptible tomato varieties. J. Integr. Agric. 2016, 15, 1785-1797.

83. Xu, D.; Zhou, G. Characteristics of siRNAs derived from Southern rice black-streaked dwarf virus in infected rice and their potential role in host gene regulation. Virol. J. 2017, 14, 27. [CrossRef] [PubMed]

84. Molnár, A.; Csorba, T.; Lakatos, L.; Várallyay, É.; Lacomme, C.; Burgyán, J. Plant virus-derived small interfering RNAs originate predominantly from highly structured single-stranded viral RNAs. J. Virol. 2005, 79, 7812-7818. [CrossRef] [PubMed] 
85. Szittya, G.; Moxon, S.; Pantaleo, V.; Toth, G.; Pilcher, R.L.R.; Moulton, V.; Burgyan, J.; Dalmay, T. Structural and functional analysis of viral siRNAs. PLoS Pathog. 2010, 6, e1000838. [CrossRef] [PubMed]

86. Qi, X.; Bao, F.S.; Xie, Z. Small RNA deep sequencing reveals role for Arabidopsis thaliana RNA-dependent RNA polymerases in viral siRNA biogenesis. PLoS ONE 2009, 4, e4971. [CrossRef]

87. Blevins, T.; Rajeswaran, R.; Aregger, M.; Borah, B.K.; Schepetilnikov, M.; Baerlocher, L.; Farinelli, L.; Meins, F., Jr.; Hohn, T.; Pooggin, M.M. Massive production of small RNAs from a non-coding region of Cauliflower mosaic virus in plant defense and viral counter-defense. Nucleic Acids Res. 2011, 39, 5003-5014. [CrossRef] [PubMed]

88. Yang, X.; Guo, W.; Ma, X.; An, Q.; Zhou, X. Molecular characterization of Tomato leaf curl China virus, infecting tomato plants in China, and functional analyses of its associated betasatellite. Appl. Environ. Microbiol. 2011, 77, 3092-3101. [CrossRef] [PubMed]

89. Wassenegger, M.; Heimes, S.; Riedel, L.; Sänger, H.L. RNA-directed de novo methylation of genomic sequences in plants. Cell 1994, 76, 567-576. [CrossRef]

90. Dalakouras, A.; Dadami, E.; Bassler, A.; Zwiebel, M.; Krczal, G.; Wassenegger, M. Replicating Potato spindle tuber viroid mediates de novo methylation of an intronic viroid sequence but no cleavage of the corresponding pre-mRNA. RNA Biol. 2015, 12, 268-275. [CrossRef] [PubMed]

91. Papaefthimiou, I.; Hamilton, A.; Denti, M.; Baulcombe, D.; Tsagris, M.; Tabler, M. Replicating potato spindle tuber viroid RNA is accompanied by short RNA fragments that are characteristic of post-transcriptional gene silencing. Nucleic Acids Res. 2001, 29, 2395-2400. [CrossRef] [PubMed]

92. Itaya, A.; Folimonov, A.; Matsuda, Y.; Nelson, R.S.; Ding, B. Potato spindle tuber viroid as inducer of RNA silencing in infected tomato. Mol. Plant-Microbe Interact. 2001, 14, 1332-1334. [CrossRef] [PubMed]

93. Itaya, A.; Zhong, X.; Bundschuh, R.; Qi, Y.; Wang, Y.; Takeda, R.; Harris, A.R.; Molina, C.; Nelson, R.S.; Ding, B. A structured viroid RNA serves as a substrate for dicer-like cleavage to produce biologically active small RNAs but is resistant to RNA-induced silencing complex-mediated degradation. J. Virol. 2007, 81, 2980-2994. [CrossRef] [PubMed]

94. Gómez, G.; Martínez, G.; Pallás, V. Viroid-induced symptoms in Nicotiana benthamiana plants are dependent on RDR6 activity. Plant Physiol. 2008, 148, 414-423. [CrossRef] [PubMed]

95. Byrne, R.T.; Waterman, D.G.; Antson, A.A. Enzyme-RNA substrate recognition in RNA-modifying enzymes. 2013.

96. de Alba, A.E.M.; Flores, R.; Hernández, C. Two chloroplastic viroids induce the accumulation of small RNAs associated with posttranscriptional gene silencing. J. Virol. 2002, 76, 13094-13096. [CrossRef]

97. St-Pierre, P.; Hassen, I.F.; Thompson, D.; Perreault, J. Characterization of the siRNAs associated with peach latent mosaic viroid infection. Virology 2009, 383, 178-182. [CrossRef] [PubMed]

98. López-Carrasco, A.; Flores, R. The predominant circular form of avocado sunblotch viroid accumulates in planta as a free RNA adopting a rod-shaped secondary structure unprotected by tightly bound host proteins. J. Gen. Virol. 2017, 98, 1913-1922. [CrossRef] [PubMed]

99. Delan-Forino, C.; Maurel, M.-C.; Torchet, C. Replication of avocado sunblotch viroid in the yeast Saccharomyces cerevisiae. J. Virol. 2011, 85, 3229-3238. [CrossRef] [PubMed]

100. Hammann, C.; Steger, G. Viroid-specific small RNA in plant disease. RNA Biol. 2012, 9, 809-819. [CrossRef] [PubMed]

101. Chen, X. MicroRNA metabolism in plants. Rna Interf. 2008, 117-136.

102. Xie, Z.; Johansen, L.K.; Gustafson, A.M.; Kasschau, K.D.; Lellis, A.D.; Zilberman, D.; Jacobsen, S.E.; Carrington, J.C. Genetic and functional diversification of small RNA pathways in plants. PLoS Biol. 2004, 2, e104. [CrossRef] [PubMed]

103. Kumar, K.V.V.; Srikakulam, N.; Padbhanabhan, P.; Pandi, G. Deciphering microRNAs and Their Associated Hairpin Precursors in a Non-Model Plant, Abelmoschus esculentus. Non-Coding RNA 2017, 3, 19. [CrossRef]

104. Blevins, T.; Rajeswaran, R.; Shivaprasad, P.V.; Beknazariants, D.; Si-Ammour, A.; Park, H.-S.; Vazquez, F.; Robertson, D.; Meins, F., Jr.; Hohn, T. Four plant Dicers mediate viral small RNA biogenesis and DNA virus induced silencing. Nucleic Acids Res. 2006, 34, 6233-6246. [CrossRef] [PubMed]

105. Deleris, A.; Gallego-Bartolome, J.; Bao, J.; Kasschau, K.D.; Carrington, J.C.; Voinnet, O. Hierarchical action and inhibition of plant Dicer-like proteins in antiviral defense. Science 2006, 313, 68-71. [CrossRef] [PubMed] 
106. Henderson, I.R.; Zhang, X.; Lu, C.; Johnson, L.; Meyers, B.C.; Green, P.J.; Jacobsen, S.E. Dissecting Arabidopsis thaliana DICER function in small RNA processing, gene silencing and DNA methylation patterning. Nat. Genet. 2006, 38, 721-725. [CrossRef] [PubMed]

107. Aliyari, R.; Ding, S.W. RNA-based viral immunity initiated by the Dicer family of host immune receptors. Immunol. Rev. 2009, 227, 176-188. [CrossRef] [PubMed]

108. Andika, I.B.; Maruyama, K.; Sun, L.; Kondo, H.; Tamada, T.; Suzuki, N. Differential contributions of plant Dicer-like proteins to antiviral defences against potato virus $X$ in leaves and roots. Plant J. 2015, 81, 781-793. [CrossRef] [PubMed]

109. Shamandi, N.; Zytnicki, M.; Charbonnel, C.; Elvira-Matelot, E.; Bochnakian, A.; Comella, P.; Mallory, A.C.; Lepère, G.; Sáez-Vásquez, J.; Vaucheret, H. Plants encode a general siRNA suppressor that is induced and suppressed by viruses. PLoS Biol. 2015, 13, e1002326. [CrossRef] [PubMed]

110. Borges, F.; Martienssen, R.A. The expanding world of small RNAs in plants. Nat. Rev. Mol. Cell Biol. 2015, 16, 727-741. [CrossRef] [PubMed]

111. Ye, R.; Chen, Z.; Lian, B.; Rowley, M.J.; Xia, N.; Chai, J.; Li, Y.; He, X.-J.; Wierzbicki, A.T.; Qi, Y. A dicer-independent route for biogenesis of siRNAs that direct DNA methylation in Arabidopsis. Mol. Cell 2016, 61, 222-235. [CrossRef] [PubMed]

112. Dalakouras, A.; Dadami, E.; Wassenegger, M. Engineering viroid resistance. Viruses 2015, 7, $634-646$. [CrossRef] [PubMed]

113. Katsarou, K.; Mavrothalassiti, E.; Dermauw, W.; Van Leeuwen, T.; Kalantidis, K. Combined activity of DCL2 and DCL3 is crucial in the defense against Potato spindle tuber viroid. PLoS Pathog. 2016, 12, e1005936. [CrossRef] [PubMed]

114. Rodríguez-Negrete, E.A.; Carrillo-Tripp, J.; Rivera-Bustamante, R.F. RNA silencing against geminivirus: Complementary action of posttranscriptional gene silencing and transcriptional gene silencing in host recovery. J. Virol. 2009, 83, 1332-1340. [CrossRef] [PubMed]

115. Ghoshal, B.; Sanfaçon, H. Symptom recovery in virus-infected plants: Revisiting the role of RNA silencing mechanisms. Virology 2015, 479, 167-179. [CrossRef] [PubMed]

116. Simon-Loriere, E.; Holmes, E.C. Why do RNA viruses recombine? Nat. Rev. Microbiol. 2011, 9, 617-626. [CrossRef] [PubMed]

117. Sanjuán, R.; Domingo-Calap, P. Mechanisms of viral mutation. Cell. Mol. Life Sci. 2016, 73, 4433-4448. [CrossRef] [PubMed]

118. Willmann, M.R.; Endres, M.W.; Cook, R.T.; Gregory, B.D. The functions of RNA-dependent RNA polymerases in Arabidopsis. Arabidopsis Book 2011, 9, e0146. [CrossRef] [PubMed]

119. Hong, W.; Qian, D.; Sun, R.; Jiang, L.; Wang, Y.; Wei, C.; Zhang, Z.; Li, Y. OsRDR6 plays role in host defense against double-stranded RNA virus, Rice Dwarf Phytoreovirus. Sci. Rep. 2015, 5, 11324. [CrossRef] [PubMed]

120. Chen, H.; Tamai, A.; Mori, M.; Ugaki, M.; Tanaka, Y.; Samadder, P.P.; Miyao, A.; Hirochika, H.; Yamaoka, N.; Nishiguchi, M. Analysis of rice RNA-dependent RNA polymerase 1 (OsRDR1) in virus-mediated RNA silencing after particle bombardment. J. Gen. Plant Pathol. 2010, 76, 152-160. [CrossRef]

121. Jiang, L.; Qian, D.; Zheng, H.; Meng, L.-Y.; Chen, J.; Le, W.-J.; Zhou, T.; Zhou, Y.-J.; Wei, C.-H.; Li, Y. RNA-dependent RNA polymerase 6 of rice (Oryza sativa) plays role in host defense against negative-strand RNA virus, Rice stripe virus. Virus Res. 2012, 163, 512-519. [CrossRef] [PubMed]

122. Quintero, A.; Pérez-Quintero, A.L.; López, C. Identification of ta-siRNAs and Cis-nat-siRNAs in Cassava and their roles in response to Cassava bacterial blight. Genom. Proteom. Bioinform. 2013, 11, 172-181. [CrossRef] [PubMed]

123. Lee, W.-S.; Fu, S.-F.; Li, Z.; Murphy, A.M.; Dobson, E.A.; Garland, L.; Chaluvadi, S.R.; Lewsey, M.G.; Nelson, R.S.; Carr, J.P. Salicylic acid treatment and expression of an RNA-dependent RNA polymerase 1 transgene inhibit lethal symptoms and meristem invasion during tobacco mosaic virus infection in Nicotiana benthamiana. BMC Plant Biol. 2016, 16, 15. [CrossRef] [PubMed]

124. Ying, X.-B.; Dong, L.; Zhu, H.; Duan, C.-G.; Du, Q.-S.; Lv, D.-Q.; Fang, Y.-Y.; Garcia, J.A.; Fang, R.-X.; Guo, H.-S. RNA-dependent RNA polymerase 1 from Nicotiana tabacum suppresses RNA silencing and enhances viral infection in Nicotiana benthamiana. Plant Cell 2010, 22, 1358-1372. [CrossRef] [PubMed]

125. Di Serio, F.; de Alba, A.-E.M.; Navarro, B.; Gisel, A.; Flores, R. RNA-dependent RNA polymerase 6 delays accumulation and precludes meristem invasion of a viroid that replicates in the nucleus. J. Virol. 2010, 84, 2477-2489. [CrossRef] [PubMed] 
126. Verlaan, M.G.; Hutton, S.F.; Ibrahem, R.M.; Kormelink, R.; Visser, R.G.; Scott, J.W.; Edwards, J.D.; Bai, Y. The tomato yellow leaf curl virus resistance genes $T y-1$ and $T y-3$ are allelic and code for DFDGD-class RNA-dependent RNA polymerases. PLoS Genet. 2013, 9, e1003399. [CrossRef] [PubMed]

127. Butterbach, P.; Verlaan, M.G.; Dullemans, A.; Lohuis, D.; Visser, R.G.F.; Bai, Y.; Kormelink, R. Tomato yellow leaf curl virus resistance by $T y-1$ involves increased cytosine methylation of viral genomes and is compromised by cucumber mosaic virus infection. Proc. Natl. Acad. Sci. USA 2014, 111, 12942-12947. [CrossRef] [PubMed]

128. Leibman, D.; Prakash, S.; Wolf, D.; Zelcer, A.; Anfoka, G.; Haviv, S.; Brumin, M.; Gaba, V.; Arazi, T.; Lapidot, M. Immunity to tomato yellow leaf curl virus in transgenic tomato is associated with accumulation of transgene small RNA. Arch. Virol. 2015, 160, 2727-2739. [CrossRef] [PubMed]

129. Llave, C. Virus-derived small interfering RNAs at the core of plant-virus interactions. Trends Plant Sci. 2010, 15, 701-707. [CrossRef] [PubMed]

130. Au, P.C.K.; Dennis, E.S.; Wang, M.-B. Analysis of Argonaute 4-Associated Long Non-Coding RNA in Arabidopsis thaliana Sheds Novel Insights into Gene Regulation through RNA-Directed DNA Methylation. Genes 2017, 8, 198. [CrossRef] [PubMed]

131. Wu, J.; Yang, Z.; Wang, Y.; Zheng, L.; Ye, R.; Ji, Y.; Zhao, S.; Ji, S.; Liu, R.; Xu, L. Viral-inducible Argonaute18 confers broad-spectrum virus resistance in rice by sequestering a host microRNA. Elife 2015, 4, e05733. [CrossRef] [PubMed]

132. Garcia-Ruiz, H.; Carbonell, A.; Hoyer, J.S.; Fahlgren, N.; Gilbert, K.B.; Takeda, A.; Giampetruzzi, A.; Ruiz, M.T.G.; McGinn, M.G.; Lowery, N. Roles and programming of Arabidopsis ARGONAUTE proteins during Turnip mosaic virus infection. PLoS Pathog. 2015, 11, e1004755. [CrossRef] [PubMed]

133. Carbonell, A.; de Alba, Á.-E.M.; Flores, R.; Gago, S. Double-stranded RNA interferes in a sequence-specific manner with the infection of representative members of the two viroid families. Virology 2008, 371, 44-53. [CrossRef] [PubMed]

134. Sano, T.; Barba, M.; Li, S.-F.; Hadidi, A. Viroids and RNA silencing: Mechanism, role in viroid pathogenicity and development of viroid-resistant plants. GM Crop. 2010, 1, 80-86. [CrossRef] [PubMed]

135. Kovalskaya, N.; Hammond, R.W. Molecular biology of viroid-host interactions and disease control strategies. Plant Sci. 2014, 228, 48-60. [CrossRef] [PubMed]

136. Wroblewski, T.; Piskurewicz, U.; Tomczak, A.; Ochoa, O.; Michelmore, R.W. Silencing of the major family of NBS-LRR-encoding genes in lettuce results in the loss of multiple resistance specificities. Plant J. 2007, 51, 803-818. [CrossRef] [PubMed]

137. Shivaprasad, P.V.; Chen, H.-M.; Patel, K.; Bond, D.M.; Santos, B.A.; Baulcombe, D.C. A microRNA superfamily regulates nucleotide binding site-leucine-rich repeats and other mRNAs. Plant Cell 2012, 24, 859-874. [CrossRef] [PubMed]

138. Ouyang, S.; Park, G.; Atamian, H.S.; Han, C.S.; Stajich, J.E.; Kaloshian, I.; Borkovich, K.A. MicroRNAs suppress NB domain genes in tomato that confer resistance to Fusarium oxysporum. PLoS Pathog. 2014, 10, e1004464. [CrossRef] [PubMed]

139. Bortolamiol, D.; Pazhouhandeh, M.; Marrocco, K.; Genschik, P.; Ziegler-Graff, V. The Polerovirus F box protein P0 targets ARGONAUTE1 to suppress RNA silencing. Curr. Biol. 2007, 17, 1615-1621. [CrossRef] [PubMed]

140. Várallyay, É.; Válóczi, A.; Ágyi, Á.; Burgyán, J.; Havelda, Z. Plant virus-mediated induction of miR168 is associated with repression of Argonaute1 accumulation. EMBO J. 2010, 29, 3507-3519. [CrossRef] [PubMed]

141. Zhang, X.; Yuan, Y.-R.; Pei, Y.; Lin, S.-S.; Tuschl, T.; Patel, D.J.; Chua, N.-H. Cucumber mosaic virus-encoded 2b suppressor inhibits Arabidopsis Argonaute1 cleavage activity to counter plant defense. Genes Dev. 2006, 20, 3255-3268. [CrossRef] [PubMed]

142. Azevedo, J.; Garcia, D.; Pontier, D.; Ohnesorge, S.; Yu, A.; Garcia, S.; Braun, L.; Bergdoll, M.; Hakimi, M.A.; Lagrange, T. Argonaute quenching and global changes in Dicer homeostasis caused by a pathogen-encoded GW repeat protein. Genes Dev. 2010, 24, 904-915. [CrossRef] [PubMed]

143. He, X.-F.; Fang, Y.-Y.; Feng, L.; Guo, H.-S. Characterization of conserved and novel microRNAs and their targets, including a TuMV-induced TIR-NBS-LRR class R gene-derived novel miRNA in Brassica. FEBS Lett. 2008, 582, 2445-2452. [CrossRef] [PubMed]

144. Qu, J.; Ye, J.; Fang, R. Artificial microRNA-mediated virus resistance in plants. J. Virol. 2007, 81, 6690-6699. [CrossRef] [PubMed] 
145. Van Vu, T.; Choudhury, N.R.; Mukherjee, S.K. Transgenic tomato plants expressing artificial microRNAs for silencing the pre-coat and coat proteins of a begomovirus, Tomato leaf curl New Delhi virus, show tolerance to virus infection. Virus Res. 2013, 172, 35-45.

146. Niu, Q.-W.; Lin, S.-S.; Reyes, J.L.; Chen, K.-C.; Wu, H.-W.; Yeh, S.-D.; Chua, N.-H. Expression of artificial microRNAs in transgenic Arabidopsis thaliana confers virus resistance. Nat. Biotechnol. 2006, 24, 1420-1428. [CrossRef] [PubMed]

147. Simón-Mateo, C.; García, J.A. MicroRNA-guided processing impairs Plum pox virus replication, but the virus readily evolves to escape this silencing mechanism. J. Virol. 2006, 80, 2429-2436. [CrossRef] [PubMed]

148. Duan, C.-G.; Wang, C.-H.; Fang, R.-X.; Guo, H.-S. Artificial microRNAs highly accessible to targets confer efficient virus resistance in plants. J. Virol. 2008, 82, 11084-11095. [CrossRef] [PubMed]

149. Lin, S.-S.; Wu, H.-W.; Elena, S.F.; Chen, K.-C.; Niu, Q.-W.; Yeh, S.-D.; Chen, C.-C.; Chua, N.-H. Molecular evolution of a viral non-coding sequence under the selective pressure of amiRNA-mediated silencing. PLoS Pathog. 2009, 5, e1000312. [CrossRef] [PubMed]

150. Ai, T.; Zhang, L.; Gao, Z.; Zhu, C.; Guo, X. Highly efficient virus resistance mediated by artificial microRNAs that target the suppressor of PVX and PVY in plants. Plant Biol. 2011, 13, 304-316. [CrossRef] [PubMed]

151. Zhang, X.; Zhao, H.; Gao, S.; Wang, W.-C.; Katiyar-Agarwal, S.; Huang, H.-D.; Raikhel, N.; Jin, H. Arabidopsis Argonaute 2 Regulates innate immunity via miRNA393*-mediated silencing of a Golgi-localized snare gene, MEMB12. Mol. Cell 2011, 42, 356-366. [CrossRef] [PubMed]

152. Kung, Y.J.; Lin, S.S.; Huang, Y.L.; Chen, T.C.; Harish, S.S.; Chua, N.H.; Yeh, S.D. Multiple artificial microRNAs targeting conserved motifs of the replicase gene confer robust transgenic resistance to negative-sense single-stranded RNA plant virus. Mol. Plant Pathol. 2012, 13, 303-317. [CrossRef] [PubMed]

153. Fahim, M.; Millar, A.A.; Wood, C.C.; Larkin, P.J. Resistance to Wheat streak mosaic virus generated by expression of an artificial polycistronic microRNA in wheat. Plant Biotechnol. J. 2012, 10, 150-163. [CrossRef] [PubMed]

154. Jelly, N.S.; Schellenbaum, P.; Walter, B.; Maillot, P. Transient expression of artificial microRNAs targeting Grapevine fanleaf virus and evidence for RNA silencing in grapevine somatic embryos. Transgenic Res. 2012, 21, 1319-1327. [CrossRef] [PubMed]

155. Ali, I.; Amin, I.; Briddon, R.W.; Mansoor, S. Artificial microRNA-mediated resistance against the monopartite begomovirus Cotton leaf curl Burewala virus. Virol. J. 2013, 10, 231. [CrossRef] [PubMed]

156. Song, Y.-Z.; Han, Q.-J.; Jiang, F.; Sun, R.-Z.; Fan, Z.-H.; Zhu, C.-X.; Wen, F.-J. Effects of the sequence characteristics of miRNAs on multi-viral resistance mediated by single amiRNAs in transgenic tobacco. Plant Physiol. Biochem. 2014, 77, 90-98. [CrossRef] [PubMed]

157. Xuan, N.; Zhao, C.; Peng, Z.; Chen, G.; Bian, F.; Lian, M.; Liu, G.; Wang, X.; Bi, Y. Development of transgenic maize with anti-rough dwarf virus artificial miRNA vector and their disease resistance. Chin. J. Biotechnol. 2015, 31, 1375-1386.

158. Kis, A.; Tholt, G.; Ivanics, M.; Várallyay, É.; Jenes, B.; Havelda, Z. Polycistronic artificial miRNA-mediated resistance to Wheat dwarf virus in barley is highly efficient at low temperature. Mol. Plant Pathol. 2016, 17, 427-437. [CrossRef] [PubMed]

159. Sun, L.; Lin, C.; Du, J.; Song, Y.; Jiang, M.; Liu, H.; Zhou, S.; Wen, F.; Zhu, C. Dimeric artificial microRNAs mediate high resistance to RSV and RBSDV in transgenic rice plants. Plant Cell Tissue Organ Cult. 2016, 126, 127-139. [CrossRef]

160. Wagaba, H.; Patil, B.L.; Mukasa, S.; Alicai, T.; Fauquet, C.M.; Taylor, N.J. Artificial microRNA-derived resistance to Cassava brown streak disease. J. Virol. Methods 2016, 231, 38-43. [CrossRef] [PubMed]

161. Mitter, N.; Zhai, Y.; Bai, A.X.; Chua, K.; Eid, S.; Constantin, M.; Mitchell, R.; Pappu, H.R. Evaluation and identification of candidate genes for artificial microRNA-mediated resistance to tomato spotted wilt virus. Virus Res. 2016, 211, 151-158. [CrossRef] [PubMed]

162. Carbonell, A.; Daròs, J.A. Artificial microRNAs and synthetic trans-acting small interfering RNAs interfere with viroid infection. Mol. Plant Pathol. 2017, 18, 746-753. [CrossRef] [PubMed]

163. Yin, Z.; Li, Y.; Han, X.; Shen, F. Genome-wide profiling of miRNAs and other small non-coding RNAs in the Verticillium dahliae-inoculated cotton roots. PLoS ONE 2012, 7, e35765. [CrossRef] [PubMed]

164. Chen, L.; Ren, Y.; Zhang, Y.; Xu, J.; Zhang, Z.; Wang, Y. Genome-wide profiling of novel and conserved Populus microRNAs involved in pathogen stress response by deep sequencing. Planta 2012, 235, 873-883. [CrossRef] [PubMed] 
165. Zhao, J.-P.; Jiang, X.-L.; Zhang, B.-Y.; Su, X.-H. Involvement of microRNA-mediated gene expression regulation in the pathological development of stem canker disease in Populus trichocarpa. PLoS ONE 2012, 7, e44968. [CrossRef] [PubMed]

166. Hua, C.; Zhao, J.-H.; Guo, H.-S. Trans-kingdom RNA silencing in Plant-Fungal Pathogen Interactions. Mol. Plant 2017. [CrossRef] [PubMed]

167. Adnan, M.; Zheng, W.; Islam, W.; Arif, M.; Abubakar, Y.S.; Wang, Z.; Lu, G. Carbon Catabolite Repression in Filamentous Fungi. Int. J. Mol. Sci. 2017, 19, 48. [CrossRef] [PubMed]

168. Islam, W.; Qasim, M.; Noman, A.; Idrees, A.; Wang, L. Genetic resistance in chickpea against Ascochyta blight: Historical efforts and recent accomplishments. J. Anim. Plant Sci. 2017, 27, 1941-1957.

169. Wang, Q.; Liu, N.; Yang, X.; Tu, L.; Zhang, X. Small RNA-mediated responses to low-and high-temperature stresses in cotton. Sci. Rep. 2016, 6, 35558. [CrossRef] [PubMed]

170. Megha, S.; Basu, U.; Kav, N.N. Regulation of low temperature stress in plants by microRNAs. Plant Cell Environ. 2017, 41, 1-15. [CrossRef] [PubMed]

171. Liang, G.; Ai, Q.; Yu, D. Uncovering miRNAs involved in crosstalk between nutrient deficiencies in Arabidopsis. Sci. Rep. 2015, 5, srep11813. [CrossRef] [PubMed]

172. Balyan, S.; Kumar, M.; Mutum, R.D.; Raghuvanshi, U.; Agarwal, P.; Mathur, S.; Raghuvanshi, S. Identification of miRNA-mediated drought responsive multi-tiered regulatory network in drought tolerant rice, Nagina 22. Sci. Rep. 2017, 7, 15446. [CrossRef] [PubMed]

173. Romo, S.; Labrador, E.; Dopico, B. Water stress-regulated gene expression in Cicer arietinum seedlings and plants. Plant Physiol. Biochem. 2001, 39, 1017-1026. [CrossRef]

174. Kim, S.; Mollet, J.-C.; Dong, J.; Zhang, K.; Park, S.-Y.; Lord, E.M. Chemocyanin, a small basic protein from the lily stigma, induces pollen tube chemotropism. Proc. Natl. Acad. Sci. USA 2003, 100, 16125-16130. [CrossRef] [PubMed]

175. Wang, J.; Feng, J.; Jia, W.; Chang, S.; Li, S.; Li, Y. Lignin engineering through laccase modification: A promising field for energy plant improvement. Biotechnol. Biofuels 2015, 8, 145. [CrossRef] [PubMed]

176. Wang, J.; Feng, J.; Jia, W.; Fan, P.; Bao, H.; Li, S.; Li, Y. Genome-wide identification of Sorghum bicolor laccases reveals potential targets for lignin modification. Front. Plant Sci. 2017, 8, 714. [CrossRef] [PubMed]

177. Gupta, O.P.; Permar, V.; Koundal, V.; Singh, U.D.; Praveen, S. MicroRNA regulated defense responses in Triticum aestivum L. during Puccinia graminis f. sp. tritici infection. Mol. Biol. Reports 2012, 39, 817-824. [CrossRef] [PubMed]

178. Zhu, Q.-H.; Fan, L.; Liu, Y.; Xu, H.; Llewellyn, D.; Wilson, I. miR482 regulation of NBS-LRR defense genes during fungal pathogen infection in cotton. PLOS ONE 2013, 8, e84390. [CrossRef] [PubMed]

179. Gupta, O.P.; Sharma, P.; Gupta, R.K.; Sharma, I. Current status on role of miRNAs during plant-fungus interaction. Physiol. Mol. Plant Pathol. 2014, 85, 1-7. [CrossRef]

180. Campo, S.; Peris-Peris, C.; Siré, C.; Moreno, A.B.; Donaire, L.; Zytnicki, M.; Notredame, C.; Llave, C.; san Segundo, B. Identification of a novel microRNA (miRNA) from rice that targets an alternatively spliced transcript of the Nramp6 (Natural resistance-associated macrophage protein 6) gene involved in pathogen resistance. New Phytol. 2013, 199, 212-227. [CrossRef] [PubMed]

181. Lu, S.; Sun, Y.H.; Chiang, V.L. Stress-responsive microRNAs in Populus. Plant J. 2008, 55, 131-151. [CrossRef] [PubMed]

182. Jagadeeswaran, G.; Saini, A.; Sunkar, R. Biotic and abiotic stress down-regulate miR398 expression in Arabidopsis. Planta 2009, 229, 1009-1014. [CrossRef] [PubMed]

183. Chen, M.; Cao, Z. Genome-wide expression profiling of microRNAs in poplar upon infection with the foliar rust fungus Melampsora larici-populina. BMC Genom. 2015, 16, 696. [CrossRef] [PubMed]

184. Fan, G.; Niu, S.; Xu, T.; Deng, M.; Zhao, Z.; Wang, Y.; Cao, L.; Wang, Z. Plant-pathogen interaction-related microRNAs and their targets provide indicators of phytoplasma infection in Paulownia tomentosa $\times$ Paulownia fortunei. PLoS ONE 2015, 10, e0140590. [CrossRef] [PubMed]

185. Lu, S.; Sun, Y.H.; Amerson, H.; Chiang, V.L. MicroRNAs in loblolly pine (Pinus taeda L.) and their association with fusiform rust gall development. Plant J. 2007, 51, 1077-1098. [CrossRef] [PubMed]

186. Li, Y.; Lu, Y.-G.; Shi, Y.; Wu, L.; Xu, Y.-J.; Huang, F.; Guo, X.-Y.; Zhang, Y.; Fan, J.; Zhao, J.-Q. Multiple rice microRNAs are involved in immunity against the blast fungus Magnaporthe oryzae. Plant Physiol. 2014, 164, 1077-1092. [CrossRef] [PubMed] 
187. Feng, H.; Zhang, Q.; Wang, Q.; Wang, X.; Liu, J.; Li, M.; Huang, L.; Kang, Z. Target of tae-miR408, a chemocyanin-like protein gene ( $T a C L P 1)$, plays positive roles in wheat response to high-salinity, heavy cupric stress and stripe rust. Plant Mol. Biol. 2013, 83, 433-443. [CrossRef] [PubMed]

188. Chen, L.; Luan, Y.; Zhai, J. Sp-miR396a-5p acts as a stress-responsive genes regulator by conferring tolerance to abiotic stresses and susceptibility to Phytophthora nicotianae infection in transgenic tobacco. Plant Cell Rep. 2015, 34, 2013-2025. [CrossRef] [PubMed]

189. Soto-Suárez, M.; Baldrich, P.; Weigel, D.; Rubio-Somoza, I.; San Segundo, B. The Arabidopsis miR396 mediates pathogen-associated molecular pattern-triggered immune responses against fungal pathogens. Sci. Rep. 2017, 7, 44898. [CrossRef] [PubMed]

190. Sun, G. MicroRNAs and their diverse functions in plants. Plant Mol. Biol. 2012, 80, 17-36. [CrossRef] [PubMed]

191. Pinweha, N.; Asvarak, T.; Viboonjun, U.; Narangajavana, J. Involvement of miR160/miR393 and their targets in cassava responses to anthracnose disease. J. Plant Physiol. 2015, 174, 26-35. [CrossRef] [PubMed]

192. Kerchev, P.I.; Karpińska, B.; Morris, J.A.; Hussain, A.; Verrall, S.R.; Hedley, P.E.; Fenton, B.; Foyer, C.H.; Hancock, R.D. Vitamin $C$ and the abscisic acid-insensitive 4 transcription factor are important determinants of aphid resistance in Arabidopsis. Antioxid. Redox Signal. 2013, 18, 2091-2105. [CrossRef] [PubMed]

193. Curaba, J.; Singh, M.B.; Bhalla, P.L. miRNAs in the crosstalk between phytohormone signalling pathways. J. Exp. Bot. 2014, 65, 1425-1438. [CrossRef] [PubMed]

194. Navarro, L.; Dunoyer, P.; Jay, F.; Arnold, B.; Dharmasiri, N.; Estelle, M.; Voinnet, O.; Jones, J.D. A plant miRNA contributes to antibacterial resistance by repressing auxin signaling. Science 2006, 312, 436-439. [CrossRef] [PubMed]

195. Pruss, G.J.; Nester, E.W.; Vance, V. Infiltration with Agrobacterium tumefaciens induces host defense and development-dependent responses in the infiltrated zone. Mol. Plant-Microbe Interact. 2008, 21, 1528-1538. [CrossRef] [PubMed]

196. Gao, S.; Jin, H. Host Small RNAs and Plant Innate Immunity. In Non Coding RNAs in Plants; Springer: Berlin/Heidelberg, Germany, 2011; pp. 21-34.

197. Zhang, W.; Gao, S.; Zhou, X.; Chellappan, P.; Chen, Z.; Zhou, X.; Zhang, X.; Fromuth, N.; Coutino, G.; Coffey, M. Bacteria-responsive microRNAs regulate plant innate immunity by modulating plant hormone networks. Plant Mol. Biol. 2011, 75, 93-105. [CrossRef] [PubMed]

198. Li, Y.; Zhang, Q.; Zhang, J.; Wu, L.; Qi, Y.; Zhou, J.-M. Identification of microRNAs involved in pathogen-associated molecular pattern-triggered plant innate immunity. Plant Physiol. 2010, 152, 2222-2231. [CrossRef] [PubMed]

199. Fahlgren, N.; Howell, M.D.; Kasschau, K.D.; Chapman, E.J.; Sullivan, C.M.; Cumbie, J.S.; Givan, S.A.; Law, T.F.; Grant, S.R.; Dangl, J.L. High-throughput sequencing of Arabidopsis microRNAs: Evidence for frequent birth and death of MIRNA genes. PLoS ONE 2007, 2, e219. [CrossRef] [PubMed]

200. Zhao, H.; Sun, R.; Albrecht, U.; Padmanabhan, C.; Wang, A.; Coffey, M.D.; Girke, T.; Wang, Z.; Close, T.J.; Roose, M. Small RNA profiling reveals phosphorus deficiency as a contributing factor in symptom expression for citrus huanglongbing disease. Mol. Plant 2013, 6, 301-310. [CrossRef] [PubMed]

201. Boccara, M.; Sarazin, A.; Thiebeauld, O.; Jay, F.; Voinnet, O.; Navarro, L.; Colot, V. The Arabidopsis miR472-RDR6 silencing pathway modulates PAMP-and effector-triggered immunity through the post-transcriptional control of disease resistance genes. PLoS Pathogens 2014, 10, e1003883. [CrossRef] [PubMed]

202. Gai, Y.-P.; Li, Y.-Q.; Guo, F.-Y.; Yuan, C.-Z.; Mo, Y.-Y.; Zhang, H.-L.; Wang, H.; Ji, X.-L. Analysis of phytoplasma-responsive sRNAs provide insight into the pathogenic mechanisms of mulberry yellow dwarf disease. Sci. Rep. 2014, 4, 5378. [CrossRef] [PubMed]

203. Srivastava, S.; Zheng, Y.; Kudapa, H.; Jagadeeswaran, G.; Hivrale, V.; Varshney, R.K.; Sunkar, R. High throughput sequencing of small RNA component of leaves and inflorescence revealed conserved and novel miRNAs as well as phasiRNA loci in chickpea. Plant Sci. 2015, 235, 46-57. [CrossRef] [PubMed]

204. Snyman, M.C.; Solofoharivelo, M.-C.; Souza-Richards, R.; Stephan, D.; Murray, S.; Burger, J.T. The use of high-throughput small RNA sequencing reveals differentially expressed microRNAs in response to aster yellows phytoplasma-infection in Vitis vinifera cv.'Chardonnay'. PLoS ONE 2017, 12, e0182629. [CrossRef] [PubMed] 
205. Yao, J.; Withers, J.; He, S.Y. Pseudomonas syringae infection assays in Arabidopsis. Jasmonate Signal. Methods Protoc. 2013, 1011, 63-81.

206. Sunkar, R.; Kapoor, A.; Zhu, J.-K. Posttranscriptional induction of two Cu/Zn superoxide dismutase genes in Arabidopsis is mediated by downregulation of miR398 and important for oxidative stress tolerance. Plant Cell 2006, 18, 2051-2065. [CrossRef] [PubMed]

207. Ali, Q.; Haider, M.Z.; Iftikhar, W.; Jamil, S.; Javed, M.T.; Noman, A.; Iqbal, M.; Perveen, R. Drought tolerance potential of Vigna mungo L. lines as deciphered by modulated growth, antioxidant defense, and nutrient acquisition patterns. Braz. J. Bot. 2016, 39, 801-812. [CrossRef]

208. Salvador-Guirao, R.; Baldrich, P.; Weigel, D.; Rubio-Somoza, I.; san Segundo, B. The microRNA miR773 is involved in the Arabidopsis immune response to fungal pathogens. Mol. Plant-Microbe Interact. 2017, 30, 249-259. [CrossRef] [PubMed]

209. Crane, Y.M.; Gelvin, S.B. RNAi-mediated gene silencing reveals involvement of Arabidopsis chromatin-related genes in Agrobacterium-mediated root transformation. Proc. Natl. Acad. Sci. USA 2007, 104, 15156-15161. [CrossRef] [PubMed]

210. Hicks, J.; Liu, H.-C. Involvement of eukaryotic small RNA pathways in host defense and viral pathogenesis. Viruses 2013, 5, 2659-2678. [CrossRef] [PubMed]

211. Gheysen, G.; Vanholme, B. RNAi from plants to nematodes. Trends Biotechnol. 2007, 25, 89-92. [CrossRef] [PubMed]

212. Ali, M.A.; Azeem, F.; Li, H.; Bohlmann, H. Smart parasitic nematodes use multifaceted strategies to parasitize plants. Front. Plant Sci. 2017, 8, 1699. [CrossRef] [PubMed]

213. Niu, J.; Liu, P.; Liu, Q.; Chen, C.; Guo, Q.; Yin, J.; Yang, G.; Jian, H. Msp40 effector of root-knot nematode manipulates plant immunity to facilitate parasitism. Sci. Rep. 2016, 6, 19443. [CrossRef] [PubMed]

214. Sindhu, A.S.; Maier, T.R.; Mitchum, M.G.; Hussey, R.S.; Davis, E.L.; Baum, T.J. Effective and specific in planta RNAi in cyst nematodes: Expression interference of four parasitism genes reduces parasitic success. J. Exp. Bot. 2009, 60, 315-324. [CrossRef] [PubMed]

215. Ibrahim, H.M.M.; Alkharouf, N.W.; Meyer, S.L.F.; Aly, M.A.M.; Abd El Kader, Y.; Hussein, E.H.A.; Matthews, B.F. Post-transcriptional gene silencing of root-knot nematode in transformed soybean roots. Exp. Parasitol. 2011, 127, 90-99. [CrossRef] [PubMed]

216. Hewezi, T.; Howe, P.; Maier, T.R.; Baum, T.J. Arabidopsis small RNAs and their targets during cyst nematode parasitism. Mol. Plant-Microbe Interact. 2008, 21, 1622-1634. [CrossRef] [PubMed]

217. Khraiwesh, B.; Zhu, J.-K.; Zhu, J. Role of miRNAs and siRNAs in biotic and abiotic stress responses of plants. Biochim. Biophys. Acta Gene Regul. Mech. 2012, 1819, 137-148. [CrossRef] [PubMed]

218. Li, X.; Wang, X.; Zhang, S.; Liu, D.; Duan, Y.; Dong, W. Identification of soybean microRNAs involved in soybean cyst nematode infection by deep sequencing. PLoS ONE 2012, 7, e39650. [CrossRef] [PubMed] 